\title{
RNA Interference and CRISPR/Cas Gene Editing for Crop Improvement: Paradigm Shift towards Sustainable Agriculture
}

\author{
Meenakshi Rajput ${ }^{1}$, Khushboo Choudhary ${ }^{1}$, Manish Kumar ${ }^{1}$, V. Vivekanand ${ }^{2}$, Aakash Chawade ${ }^{3, *}$, \\ Rodomiro Ortiz ${ }^{3}$ (i) and Nidhi Pareek ${ }^{1, *}$ \\ 1 Department of Microbiology, School of Life Sciences, Central University of Rajasthan, \\ Ajmer 305801, Rajasthan, India; 2019phdmb07@curaj.ac.in (M.R.); 2019phdmb0003@curaj.ac.in (K.C.); \\ 2014phdmb04@curaj.ac.in (M.K.) \\ 2 Centre for Energy and Environment, Malaviya National Institute of Technology, \\ Jaipur 302017, Rajasthan, India; vivekanand.cee@mnit.ac.in \\ 3 Department of Plant Breeding, Swedish University of Agricultural Sciences, P.O. Box 101, \\ 23053 Alnarp, Sweden; rodomiro.ortiz@slu.se \\ * Correspondence: aakash.chawade@slu.se (A.C.); nidhipareek@curaj.ac.in (N.P.)
}

check for updates

Citation: Rajput, M.; Choudhary, K.; Kumar, M.; Vivekanand, V.; Chawade, A.; Ortiz, R.; Pareek, N. RNA Interference and CRISPR/Cas Gene Editing for Crop Improvement: Paradigm Shift towards Sustainable Agriculture. Plants 2021, 10, 1914. https://doi.org/10.3390/ plants10091914

Academic Editor: Baohong Zhang

Received: 30 June 2021

Accepted: 26 August 2021

Published: 14 September 2021

Publisher's Note: MDPI stays neutral with regard to jurisdictional claims in published maps and institutional affiliations.

Copyright: (c) 2021 by the authors. Licensee MDPI, Basel, Switzerland. This article is an open access article distributed under the terms and conditions of the Creative Commons Attribution (CC BY) license (https:/ / creativecommons.org/licenses/by/ $4.0 /)$.

\begin{abstract}
With the rapid population growth, there is an urgent need for innovative crop improvement approaches to meet the increasing demand for food. Classical crop improvement approaches involve, however, a backbreaking process that cannot equipoise with increasing crop demand. RNA-based approaches i.e., RNAi-mediated gene regulation and the site-specific nuclease-based CRISPR/Cas9 system for gene editing has made advances in the efficient targeted modification in many crops for the higher yield and resistance to diseases and different stresses. In functional genomics, RNA interference (RNAi) is a propitious gene regulatory approach that plays a significant role in crop improvement by permitting the downregulation of gene expression by small molecules of interfering RNA without affecting the expression of other genes. Gene editing technologies viz. the clustered regularly interspaced short palindromic repeat (CRISPR)/CRISPR-associated protein (CRISPR/Cas) have appeared prominently as a powerful tool for precise targeted modification of nearly all crops' genome sequences to generate variation and accelerate breeding efforts. In this regard, the review highlights the diverse roles and applications of RNAi and CRISPR/Cas9 system as powerful technologies to improve agronomically important plants to enhance crop yields and increase tolerance to environmental stress (biotic or abiotic). Ultimately, these technologies can prove to be important in view of global food security and sustainable agriculture.
\end{abstract}

Keywords: crop; CRISPR/Cas9; resistance; RNA interference; stress

\section{Introduction}

Food plays a vital role in the existence of human life on earth. With a rapidly growing population, it is, however, very difficult to fulfill the increasing demand for food globally by using traditional methods of crop improvement. People are making continuous efforts to improve crop yield, nutrient content, and to make disease-resistant crops by using conventional methods of crop improvement. Unfortunately, these plant breeding methods are not viable with the current needs of a fast-growing population as these approaches are laborious and time-consuming.

It has been evaluated that by the year 2050, there is an urgent need for increasing food production by $70 \%$ to feed the expanding population globally [1]. At present, a range of approaches such as crossbreeding, transgenic breeding and mutation breeding are in practice for the production of genotypes that are disease-resistant and resilient to climate change and other stresses. However, crossbreeding and mutation breeding are untargeted breeding methods with really backbreaking processes, while the production and commercialization process of the genotypes produced also faces many limitations, whereas 
in the case of transgenic breeding, apart from the long and costly commercialization process, genetically modified crops also encounter the challenge of public acceptance [2].

Recently, many advances have been made in the RNA-based gene regulation approach, i.e., RNA interference (RNAi), a gene regulatory tool that has been significantly diversified for crop improvement by modifying the expression of the gene for better trait quality with fewer biosafety issues as an expression of the transgene that is absent in transgenic lines. RNAi is a gene silencing phenomenon, which can be employed for the assessment of gene function, plant metabolic engineering, and in the development of stress-tolerant and disease-resistant crops [3].

Over the past five years, the RNA-guided nucleases-based gene editing approach i.e., the clustered regularly interspaced short palindromic repeat (CRISPR)/CRISPR-associated protein (CRISPR/Cas), has been recognized as an efficient tool for targeted gene editing in crops [4]. CRISPR allows targeting a sequence for gene knockin, knockout, and replacement along with observing and regulating gene expression by binding a specific sequence at the genome and epigenome levels. The genome editing function of CRISPR depends upon the three components viz. CRISPR RNA (crRNA), CRISPR-associated enzymes (Cas), and trans-activating crRNA (tracRNA). These three components can be constructed together to form a single chimeric synthetic RNA molecule known as single-guide RNA (sgRNA) for genome editing functions [4]. CRISPR provides the possibilities of targeting multiple genes simultaneously along with the ease of multiple editing. Thus, it has been widely used to edit, regulate, and monitor genes not only in plants but also in bacteria and animals. For genome modification, dsDNA breaks are introduced at specific locations by site-specific nucleases, which further stimulates DNA repair mechanisms, i.e., nonhomologous end joining (NHEJ) and homology-directed repair (HDR) to introduce specific genome modifications. The NHEJ pathway works by ligating the broken ends of DSB without using homologous DNA, which results in insertions or deletions (InDels) or singlenucleotide polymorphism (SNP) at the cut site leading to frameshift or nonsense mutations. In the case of HDR, gene replacement takes place with the help of a homologous template at the breakpoint. Therefore, both NHEJ and HDR play an important role in nucleasebased gene editing [5]. In crop breeding, this approach generates the transgene-free bred cultivars. In this regard, this review encompasses various roles and possible applications of RNAi and the RNA-guided CRISPR/Cas9 system as powerful technologies to improve agronomically important crops to significantly enhance crop yields and tolerance to various environmental stress agents of both biotic and abiotic origin. Limitations, challenges, and potential future development have also been discussed.

\section{RNA Interference}

RNA interference is an evolutionarily conserved, naturally occurring, gene regulatory phenomenon in eukaryotic cells. It has been evolved to protect cells against invading foreign DNA. Besides this, it also helps in maintaining genomic stability, transposon movement regulation, epigenetic modification, and controls cellular processes at transcriptional and translational levels $[6,7]$. The gene silencing phenomenon was unfolded accidentally in Petunia flowers when Napoli et al. [8] were experimenting to deepen the color of petunia flowers by upregulating the gene coding for pigment production, which surprisingly resulted in variegated flowers instead of expected deep purple flowers. Since the expression of a homologous endogenous gene, as well as a transgene, was suppressed, the phenomenon was called "co-suppression" [8]. Fire et al. [9] discovered the same phenomenon in the nematode Caenorhabditis elegans, when they injected dsRNA in C. elegans, which resulted in efficient silencing of the target endogenous gene homologous to RNA, hence the phenomenon was named RNA interference (RNAi) [9]. This turned out to be one of the most compelling discoveries in biotechnology, because of its targeted gene regulation, accuracy, and heritability [10,11]. The gene expression in plants can be regulated through plant endogenous small RNAs (sRNAs) and it can be divided into endogenous short interfering RNAs (siRNAs) and microRNAs (miRNAs) [12]. The locus annotations of siRNAs 
are behind miRNAs, which have well-annotated loci. However, miRNAs consist of a small portion of the total sRNA pool. Moreover, miRNAs are more conserved as compared to siRNA across species [12]. The miRNAs can be applied to achieve simultaneous silencing of multiple targets through the production of polycistronic miRNA precursors [13]. Moreover, the segregation of the RNAi transgene has been reported to produce non-genetic MSH1 (a plant-specific mitrochondrial-and plastid-targeting protein) memory, which can be inherited in multiple generations [14]. The study suggested that RNAi suppression of MSH1 could lead to inconsistency in the phenotype related to the developmental and stress response pathways.

Similar mechanisms have also been observed in fungi as "quelling" [15] bacteria such as the CRISPR/Cas system [16], algae [17], fruit fly [18], and mammals [19]. Since then, research in this field has been burgeoning and researchers feel that RNAi is a promising tool for gene regulation with greater potential as compared to other post-transcriptional gene regulation technologies such as antisense technology. RNAi is a naturally occurring phenomenon in eukaryotes with its oldest and omnipresent antiviral defense system, whereas almost all antisense RNAs are found in prokaryotes [20].

In this biological process, small non-coding RNAs (21-28 nt. long), which participate in the gene regulation, are the cleavage product of dsRNAs, i.e., microRNA (miRNA) and small interfering RNA (Si RNA). The process of cleavage is carried out by a multidomain endoribonuclease named Dicer or the Dicer-like enzyme, which belongs to the RNase III family [21]. Finally, these small non-coding RNAs (ncRNA) are associated with the RNA-induced silencing complex (RISC), argonaute (AGO) [22], and other effector proteins, and cause complex degradation of the target messenger RNA [16,23]. Thus, RNAi can be defined as the capability of endogenous or exogenous dsRNA to inhibit the expression of the gene whose sequence is complementary to dsRNA [24].

\subsection{RNAi Mechanism}

\subsubsection{Components of RNAi Machinery}

Two ribonucleases participate in the RNAi pathway-first, Dicer and second, the RNA-induced silencing complex (RISC), where Dicer cleaves the dsRNA into active small non-coding RNAs and initiates the RNAi pathway [21], while RISC with the RNase H core enzyme Argonaute (AGO) accomplishes the gene silencing [22]. The Dicer family belongs to the class 3 RNase III enzyme and consists of four domains: N-terminal helicase domain, a PAZ (Piwi/Argonaute/Zwille) domain, dual RNase III domains, and a dsRNA binding domain. The primary function of these enzymes is to recognize the dsRNA precursor from the RNAi pathway and to generate small non-coding RNA of a specific length (21-24 nt long). The Dicer catalysis model proposes that in the multidomain dicer enzyme, two RNase III domains dimerize and form an intramolecular pseudo-dimer, which serves as the active center. It has also been suggested that each domain cuts a single strand of dsRNA, forming a new terminus [25]. Finally, the last step of the RNAi pathway, i.e., gene silencing by target mRNA degradation, is performed by RISC in association with the argonaute (AGO) protein and other effector proteins. Argonaute proteins are primarily found in bacteria, archaea, and eukaryotes. The significant function of the Argonaute protein is to recognize guide strand termini, cleave the target mRNA with its nuclease activity, or recruit other proteins involved in silencing. RISC with gene silencing also participates in the cellular surveillance process $[16,20]$.

\subsubsection{Mechanism of Action}

Over the last two decades, the functionality of small non-coding RNA in gene regulatory processes of transcriptional gene silencing (TGS) and post-transcriptional gene silencing (PTGS) has continuously been explored. Various classes of small non-coding RNAs have been discovered so far. These include miRNA, siRNA, piRNA (PIWI-interacting RNA), qiRNA (QDE-2-interacting RNA), svRNA (small vault RNA), etc., having different biogenesis pathways and regulatory mechanisms [26]. Initially, the process of biogenesis of 
miRNA and siRNA differs to form their corresponding dsRNA precursors as the cellular origin of miRNA is the genomic DNA, whereas siRNA can be generated endogenously via cleavage of dsRNA into smaller segments or it can be exogenously derived directly from the viruses, transposons, or transgene. Regardless of these differences, they have similarities in their sizes and sequence-specific inhibitory functions, which clearly suggest that their respective biogenesis pathways and mechanisms are related to each other somehow. The RNAi pathway comprised four steps: The formation of snRNA as a cleavage product of dicer, loading of snRNA into the RISC complex, activation of the silencing complex, and target mRNA degradation [20].

\subsection{Micro RNA (miRNA)}

miRNAs are 21-24 nucleotide (nt)-long small RNAs, which are derived from MIR genes. The biogenesis of miRNA occurs in the nucleus by RNA polymerase II aided transcription of MIR genes, forming a primary miRNA (pri-miRNA) transcript of about 1000 nt (Figure 1). Due to the presence of intramolecular sequence complementarity in pri-miRNA, an imperfect folded-back stem-loop or hairpin structure formation takes place, which is further processed into a short stem-loop precursor known as pre-miRNA with the aid of DCL1 assisted by the dsRNA binding protein DRB1or HYL1 [27]. This pre-miRNA is again cropped by DCL1 in the nucleus and generates the RNA duplex (miRNA:miRNA*), which consists of mature miRNA (guide strand) and miRNA* (passenger strand) [28]. The $3^{\prime}$-terminals of the RNA duplex get methylated by HUA ENHANCER (HEN1) at the 2'-Ohydroxyl group to prevent degradation of miRNA:miRNA* $[29,30]$. After methylation, the RNA duplex is exported to the cytoplasm where mature miRNA is loaded onto the RISC complex with AGO and other effector proteins. This miRNA-induced silencing complex (miRISC) base pairs with the complementary target mRNA completely, then the AGO protein with its characteristic nuclease activity degrades the target mRNA [31]. In the case that complete base pairing does not occur between miRISC and the target mRNA, then miRISC inhibits the translation process.

In 2011, Huntzinger and Izaurralde suggested that miRNA-mediated downregulation of gene expression occurs by (1) miRISC-mediated inhibition of translational initiation or ribosome subunit joining, premature degradation of the budding polypeptide chain, and an increase in drop off of the ribosome; or (2) inducing deadenylation and destabilization of the target mRNA [32]. Expression of miRNA is usually witnessed during the phase of plant growth and development, secondary metabolite synthesis, abiotic and biotic stress, etc. Hence, a change in expression and biogenesis of these RNAs could lead to the formation of the crop with agronomically valuable characteristics [33].

\subsection{Small Interfering RNA (siRNA)}

Gene silencing through RNAi can be triggered via long dsRNA or short hairpin precursors, which can perfectly base pairs with the gene to be silenced. The introduction of long endogenous dsRNA directly into the cytoplasm or access of transgene, viral intruders, or transposable elements can ignite the RNAi pathway by recruiting the Dicer or Dicer-like enzymes [34]. This Dicer enzyme crops these dsRNAs into short 21-24 nt long SiRNA duplexes with 2 nt overhangs at the $3^{\prime} \mathrm{OH}$ end and $5^{\prime}$ phosphorylated ends $[35,36]$. Thereafter, the SiRNA-induced silencing complex (SiRISC) is recruited and degrades the sense strand (has precisely the same sequence as that of target mRNA) of SiRNA, whereas the antisense strand of siRNA along with siRISC get loaded onto the target mRNA in a sequence-specific manner (Figure 2). siRISC incorporation with the AGO protein and other effector proteins leads to post-transcriptional gene silencing (PTGS) by cleavage of the target mRNA or inhibition of translation [37]. Aside from this, siRNAs by chromatin regulation can also participate in the co-transcriptional gene silencing. Dicer-independent siRNA genesis has also been reported in Neurospora, C. elegans, Schizosaccharomyces pombe, and Arabidopsis [38-41]. These dicer-independent siRNAs mostly arise from transposable elements, intergenic elements, and transgenes [41]. 


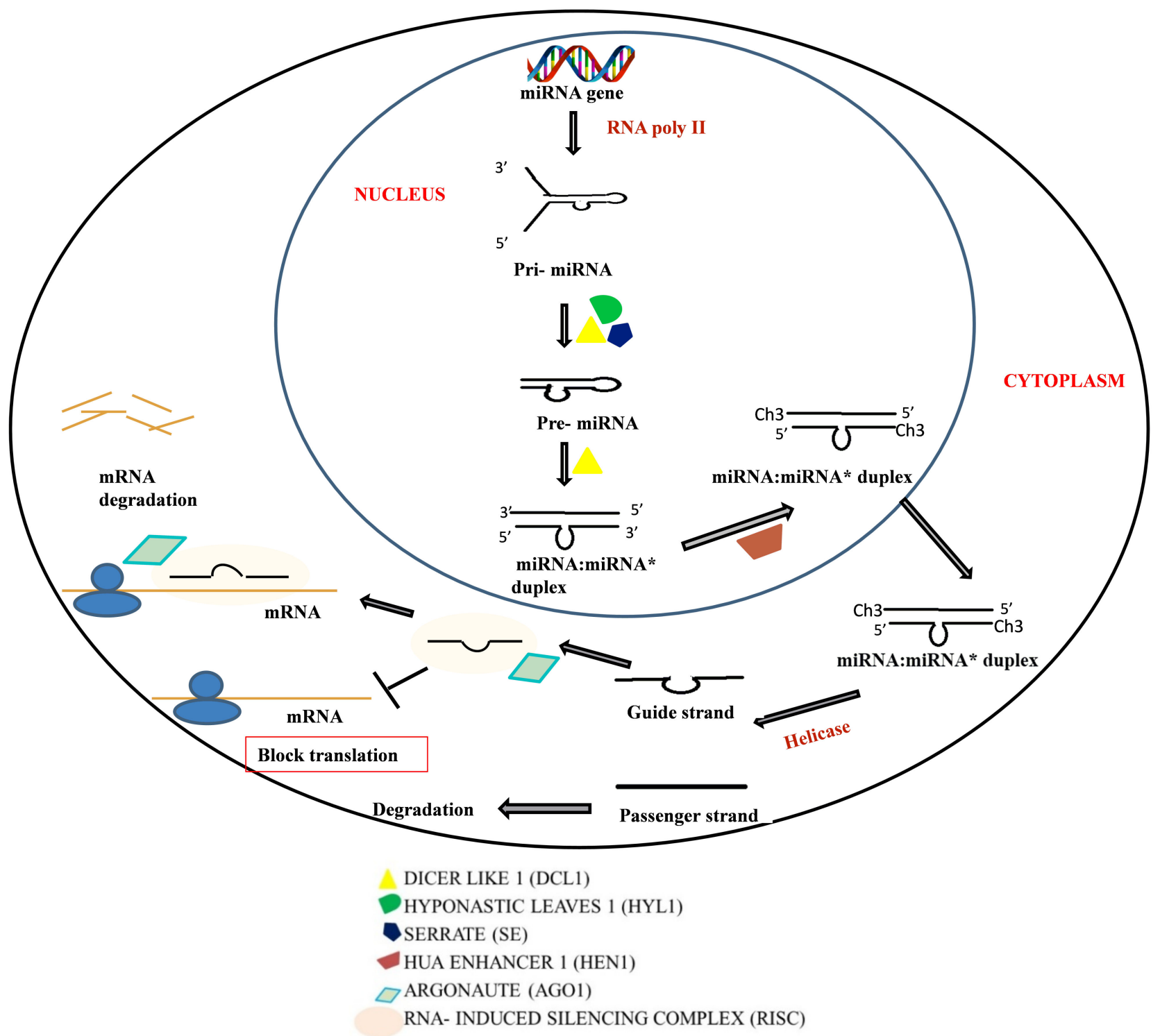

Figure 1. Mechanism of miRNA biogenesis and gene silencing. The miRNA biogenesis commences with the transcription of miRNA genes into pri-miRNA by RNA polymerase II, which is further subjected to primary and secondary processing via the enzyme complex of DCL-1, SE, and HYL1 leading to the generation of pre-miRNA and an miRNA/miRNA* duplex, respectively. Further the HEN1-mediated methylation at the $3^{\prime}-\mathrm{OH}$ end leads to the export of the duplex to the cytoplasm. In the cytoplasm, the passage RNA strand is degraded and the guide strand from the miRNA-inducing silencing complex (miRISC) directs the degradation or translation inhibition of the target mRNA. 

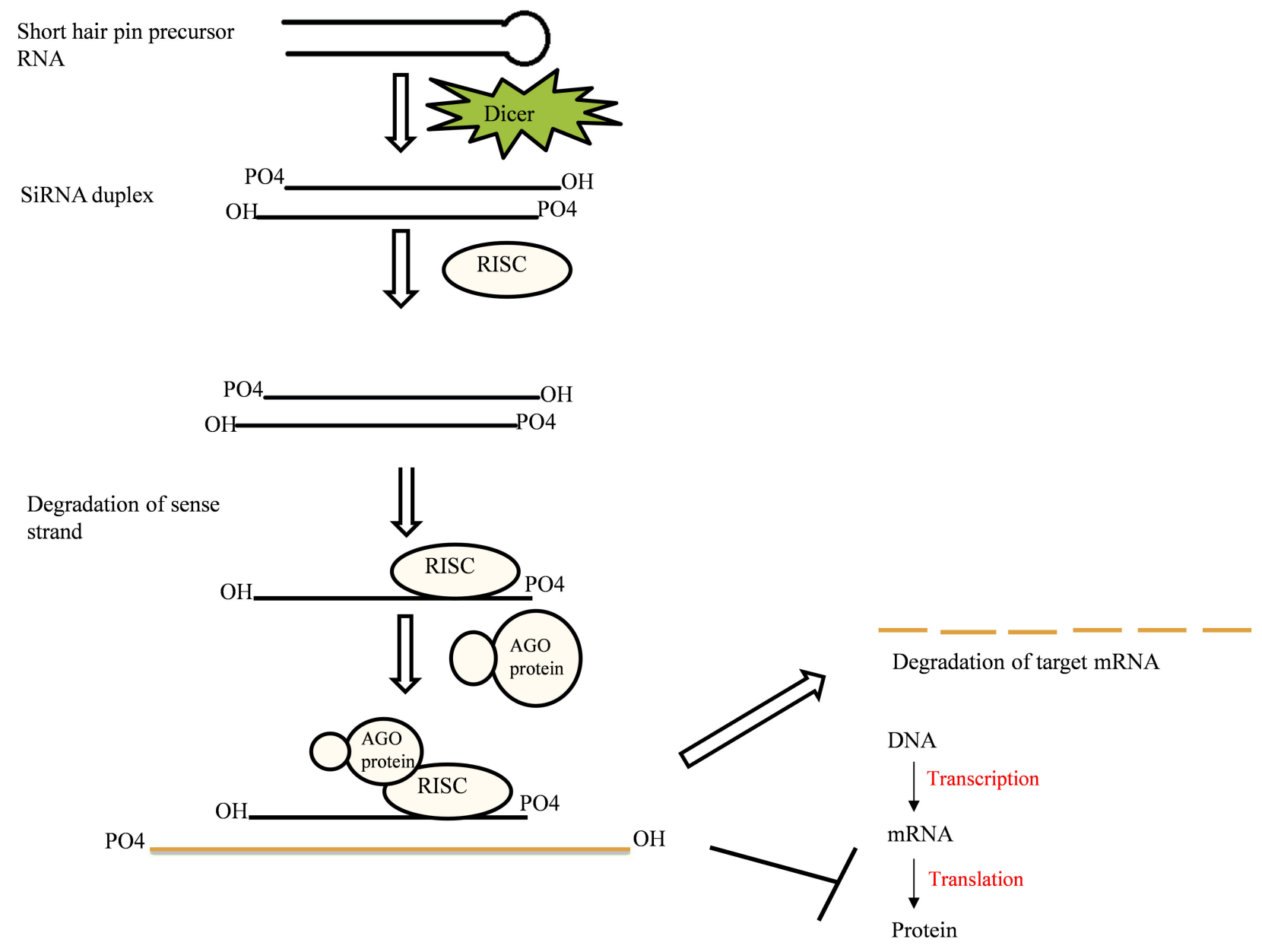

Figure 2. siRNA biogenesis and gene silencing. Here the action of Dicer or the Dicer-like enzyme on the precursor RNA results in an siRNA duplex with overhangs at $3^{\prime}-\mathrm{OH}$ ends. Further, the antisense strand from siRNA induces the silencing complex by associating with the RISC protein. Thereafter, incorporation of AGO and other effector proteins with siRISC facilitate the gene silencing through degradation of the target mRNA or translation inhibition.

\subsection{Role of RNAi in Crop Improvement}

In the 21st century, one of the major goals is to provide food security and stop the malnutrition across the world, but factors such as abiotic and biotic stresses, anthropogenic effects, climate change, and depletion of natural resources limit the crop production globally $[1,42]$. Thus, to overcome these problems, genetic engineering should be used in a way to manipulate the physiology of plants, genomes, and proteomes. In this context, RNAi has been extensively explored by researchers for improving a range of crop features including stress tolerance, disease resistance, yield enhancement, etc. (Table 1). 
Table 1. Crops with improved stress tolerance through RNAi.

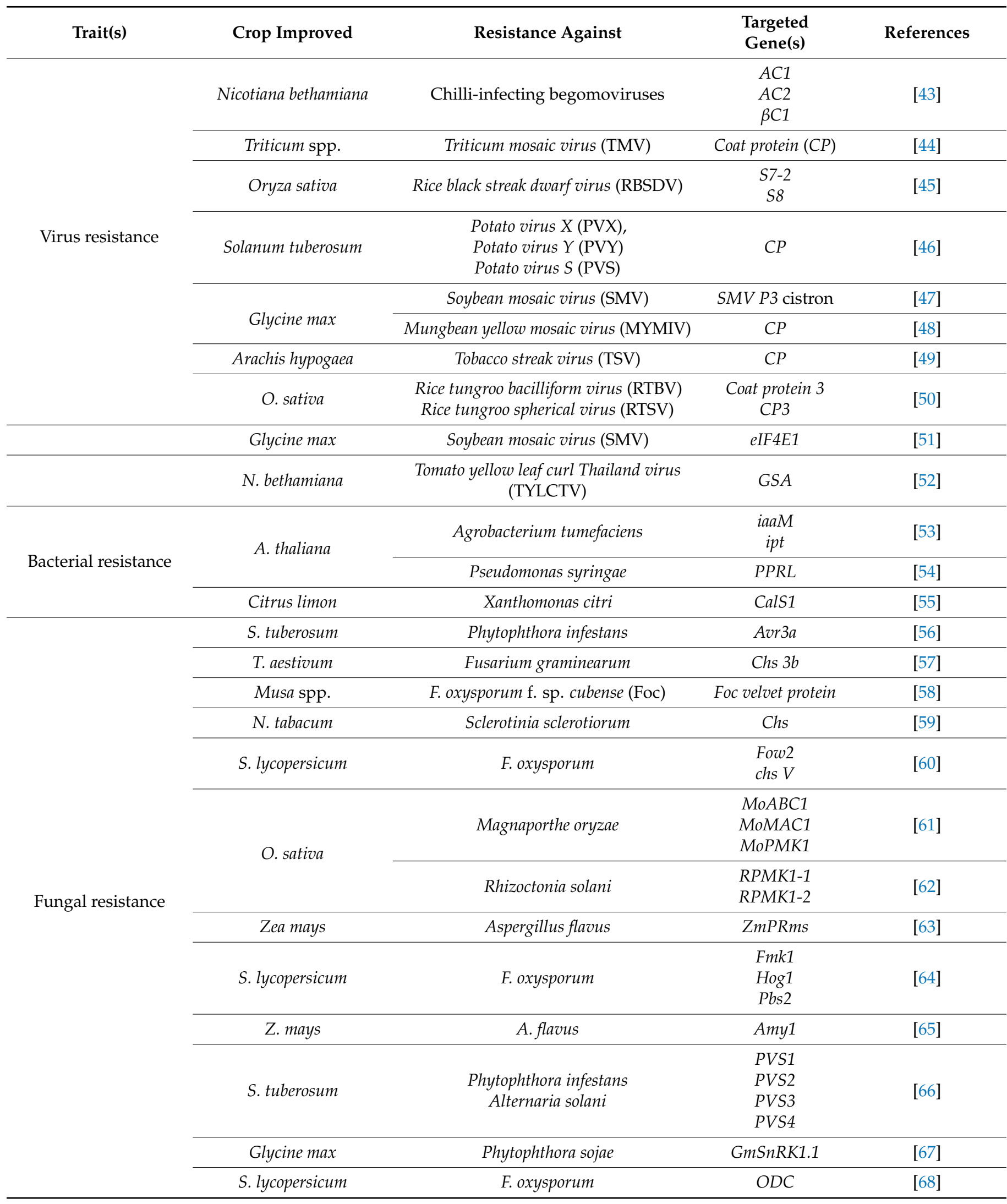


Table 1. Cont.

\begin{tabular}{|c|c|c|c|c|}
\hline Trait(s) & Crop Improved & Resistance Against & $\begin{array}{l}\text { Targeted } \\
\text { Gene(s) }\end{array}$ & References \\
\hline \multirow{8}{*}{$\begin{array}{l}\text { Virus resistance } \\
\text { Insect resistance }\end{array}$} & & & $A C 1$ & \\
\hline & Nicotiana bethamiana & Chilli-infecting begomoviruses & $A C 2$ & [43] \\
\hline & & & $\beta C 1$ & \\
\hline & S. lycopersicum & Helicoverpa armigera & $\mathrm{HaCHI}$ & [69] \\
\hline & N. tabacum & Bemisia tabaci & $\begin{array}{c}A C h E \\
E c R\end{array}$ & {$[70]$} \\
\hline & Lettuce & B. tabaci & $V$-ATPase & [71] \\
\hline & A. thaliana & Myzus persicae & $M y C P$ & [72] \\
\hline & Brassica rapa & Tetranychus urticae & COPB2 & [73] \\
\hline \multirow{8}{*}{$\begin{array}{l}\text { Nematodes } \\
\text { Resistance }\end{array}$} & S. lycopersicum & Meloidogyne incognita & Mi-cpl1 & [74] \\
\hline & N. benthamiana & Radopholus similis & Rs-cps & [75] \\
\hline & S. lycopersicum & M. incognita & PolA1 & [76] \\
\hline & \multirow{2}{*}{ Glycine max } & Heterodera glycines & Hg16B09 & [77] \\
\hline & & & HgY25 HgPrp17 & [78] \\
\hline & \multirow{3}{*}{ A. thaliana } & \multirow{3}{*}{ M. incognita } & Mi-msp3 & \multirow{3}{*}{ [79] } \\
\hline & & & Mi-msp 5 & \\
\hline & & & $\begin{array}{l}\text { Mi-msp18 } \\
\text { Mi-msp24 }\end{array}$ & \\
\hline \multirow{11}{*}{$\begin{array}{l}\text { Abiotic stress } \\
\text { tolerance }\end{array}$} & N. tabacum & Salt tolerance & $N t \varepsilon-L C Y$ & [80] \\
\hline & O. sativa & Salt tolerance & OsPEX11 & [81] \\
\hline & B. rapa & Salt tolerance & GIGANTEA (GI) & [82] \\
\hline & A. thaliana & Drought tolerance & $\begin{array}{c}\text { PAD4 } \\
\text { LSD1 EDS1 }\end{array}$ & [83] \\
\hline & O. sativa & Drought tolerance & OsGRXS17 & [84] \\
\hline & O. sativa & Drought tolerance & OsDSR-1 & [85] \\
\hline & O. sativa & Drought tolerance & OsERF101 & [86] \\
\hline & S. lycopersicum & Drought and salt tolerance & SlbZIP1 & [87] \\
\hline & N. tabacum & Drought tolerance & BrDST71 & [88] \\
\hline & T. aestivum & Salt tolerance & TaPUB-1 & [89] \\
\hline & A. thaliana & Osmotic tolerance & WZY2 & [90] \\
\hline
\end{tabular}

\subsubsection{Biotic Stress Resistance}

In plants, biotic stress is caused by living organisms, especially viruses, bacteria, fungi, insects, arachnids, nematodes, and weeds. These organisms account for about a $40 \%$ loss in the overall yield of six major food and cash crops [91]. RNAi technology has opened up new prospects for crop protection against biotic stresses.

\section{RNAi-Mediated Virus Resistance}

Viruses are the leading agents behind the major loss of crop productivity as it is very difficult to control them due to their diverse strategies to multiply and transmit diseases in the host plant. Therefore, pathogen-derived resistance (PDR) has been considered as one of the most efficient approaches in fighting viral infections in plants. However, there is one more approach, i.e., RNA interference that provides broad-spectrum resistance against viral infections by targeting multiple regions of a viral gene. It relies on the principle of targeted silencing of the viral coat proteins (CP). In 1998, the first RNAi-mediated virus- 
resistant potato transgenic lines were reported, which were transformed by simultaneous expression of both sense and antisense transcripts of the helper-component (HC-Pr) gene and showed complete resistance against Potato virus Y (PVY) [92]. Missiou et al. [93] developed potato transgenic lines that were highly resistant to three strains of PVY by expressing the dsRNA derived from the $3^{\prime}$-terminal end part of viral coat proteins (CP), which has been reported as the highly conserved region of PVY isolates. Over recent years, many RNAi-mediated virus-resistant cultivars targeting the viral coat protein have been produced i.e., Beet necrotic yellow vein virus (BNYVV)-resistant tobacco [94], Plum pox virus (PPV)-resistant Prunus domestica and N. benthamiana [95], and Bean golden mosaic virus (BGMV)-resistant Phaseolus vulgaris [96].

Si-RNA-mediated silencing of the African cassava mosaic virus (ACMV) by targeting the replication-associated protein 1 (AC1) resulted in a 66\% decrease in ACMV genomic DNA [97]. In 2009, Vanderschuren et al. [98] performed an experiment in which they developed dose-dependent RNAi-mediated transgenic cassava lines resistant to ACMV. Cassava brown streak disease (CBSD) is considered one of the threats for cassava (Manihot esculenta) cultivation in East Africa. In this regard, Patil et al. [99] first developed cassava plants resistant to CBSD and provided protection against two causative organisms belonging to two different species, i.e., the Cassava brown streak virus (CBSV) and the Cassava brown streak Uganda virus (CBSUV) by using RNAi construct containing 397-nt from N-terminal end and 491-nt from the C-terminal end of the coat protein gene of the viruses [99].

Tobacco streak virus (TSV)-resistant transgenic lines of both tobacco and sunflower (Helianthus annuus L.) were produced by RNAi technology using a 421-bp-long coat protein gene containing both sense and anti-sense coat protein sequences [100]. Rice strip disease caused by the Rice strip virus (RSV) was successfully suppressed in two RSV-susceptible varieties of Japonica by RNAi construct consisting of the CP gene and the disease-specific (SP) gene [101]. Soybean mosaic virus (SMV)-resistant transgenic lines of soybean were produced by introducing a hairpin RNAi construct containing the Hc-Pro gene [102]. Peanut (Arachis hypogaea L.) plants resistant to the Tobacco streak virus were developed using hairpin RNA comprising TSV-coat proteins.

Pooggin et al. [103] demonstrated that DNA of a replicating virus can be used as an RNAi target. They used this approach in the silencing gene associated with bidirectional promoters and witnessed recovery from infection of the Mungbean yellow mosaic India virus (MYMIV) in Vigna mungo.

A study conducted on N. benthamiana and Vigna unguiculata plants to develop resistance against the Bean common mosaic virus (BCMV) by exogenous application of RNAi construct containing viral coat proteins to protect plants from aphid mediated transmission of BCMV [104]. Rice tungroo bacilliform virus (RTBV)- and Rice tungroo spherical virus (RTSV)-resistant $O$. sativa cultivars have been developed by using a highly conserved coat protein 3 (CP3) gene in an RNAi construct. They observed high resistance in O. sativa against tungroo disease, and the ability to transmit the virus has also been decreased in transgenic lines [50].

\section{RNAi-Mediated Bacterial Resistance}

Bacteria serve as the biggest hurdle in crop production as they are ubiquitous in nature as well as replicating with great speed and causing infection. Hence, it is important to produce bacterial-resistant crops. Escobar et al. [53] conducted a study on $A$. thaliana and S. lycopersicum (tomato) to suppress crown gall disease caused by Agarobacterium tuminifaciens through RNAi technology. For this, they designed dsRNA construct homologous to oncogenes iaaM and ipt, which are necessary for tumor formation. Katiyar-Agarwal et al. [54] demonstrated that P. syringae infection in A. thaliana induced biogenesis of endogenous si-RNA i.e., nat-SiRNAATGB2. This siRNA downregulated the expression of the PPRL gene, which is considered a negative regulator of the RPS2 resistance pathway. 
RNAi-Mediated Fungal Resistance

Research findings suggest that RNAi technology can be used to enhance resistance against fungi in genetically engineered crops. Gene silencing has been studied using homologous transgenes (co-suppression), antisense or dsRNAs in many plant-pathogenic fungi such as Cladosporium fulvum [105], Venturia inaequalis [106], N. crassa [107], and Magnaporthe oryzae [108]. Enhancement of resistance against Phytophthora parasitica var. nicotianae has been observed in N. tobacum by downregulation of the GST (glutathione S-transferase) enzyme gene via RNAi [109]. Fusarium wilt has been classified among the most destructive diseases of banana, caused by F. oxysporum f. sp. Cubense (Foc). Banana transgenic lines developed by intron hairpin RNA (ihp-RNA)-mediated expression of si-RNA has shown enhancement in resistance against Foc. This was achieved by the downregulation of a vital gene of Foc fungus and confirmed by performing 6-week-long bioassays in the greenhouse [58]. Chen et al. [110] explored the role of RNAi machinery in the causative agent of wheat head blight, i.e., Fusarium graminearum by the aid of hpRNA for silencing the target mRNA. They also studied the importance of FgAgo (Argonaute protein) and FgDicer2 in gene silencing.

Agarobacterium-mediated transformation (AMT) of RNAi constructs act as a potent approach for investigating the role of the gene involved in pathogenesis. Transformation of F. oxysporum spores using RNAi construct of three MAP Kinase signaling genes (viz. Fmk1, Hof1, and Pbs2) via AMT resulted in reduced invasive growth on tomato fruits, pathogenesis, loss of surface hydrophobicity, and hypo-virulence on tomato seedlings [64].

Functional analysis of the membrane-localized gene GmSnRK1.1, important for soybean resistance against Phytophthora sojae, has been done by overexpressing the gene and RNAi silencing. Results obtained show that overexpression of genes increase the resistance whereas RNAi-mediated silencing leads to a reduction in resistance [67].

\section{RNAi-Mediated Insects and Nematode Resistance}

Insects and nematodes are capable of causing severe damage to the crops. Some of the most disastrous nematodes are Meloidogyne spp., Heterodera and Globodera spp., Pratylenchus spp., Helicotylenchus spp., Radopholus similis, Ditylenchus dipsaci, Rotylenchulus reniformis, Xiphinema spp., and Aphelenchoides spp. [111]. Gheysen and Vanholme [112] suggested that the expression of dsRNA targeting the housekeeping gene and the parasitism gene of root-knot nematodes (RKN) in a host plant led to resistance against nematode infection. Bioengineering of crops expressing dsRNA that targets the RKN parasitism gene could help in providing broad-spectrum resistance to crop against RKN [113].

Cyst nematodes are considered to be highly evolved sedentary endoparasites that cause great damage to the crops globally. Through host-induced RNAi silencing, all four parasitism genes of the sugar beet cyst nematode (Heterodera schachtii) were targeted with $A$. thaliana as the host, resulting in a decrease in the number of female nematodes. No complete resistance was observed, however, but the reduction in developing nematodes ranges 23$64 \%$ in different RNAi lines [114]. Similarly, enhanced resistance against the soybean cyst nematode $\mathrm{H}$. glycines has been reported by targeting reproduction and fitness-related genes, i.e., $H g Y 25$ and $H g P r p 17$ in soybean transgenic lines [78].

RNAi-mediated root-knot nematode (Meloidogyne incognita) resistance was pursued in A. thaliana for targeting two housekeeping genes i.e., splicing factor (349 bp) and integrase enzymes $(624 \mathrm{bp})$. Splicing factor and integrase enzyme are important for nematodes as they play a prominent role in RNA metabolism. Hence, their RNAi-mediated silencing resulted in a significant decrease in the number of galls, females, and egg masses [115]. Tsygankova et al. [116] examined RNAi-mediated invitro resistance in bread wheat (T. aestivum L.) against the parasitic nematode $H$. avenae using bioregulators of microbial origin.

The success of the cry toxin from Bacillus thuringiensis as an insecticide has led to the foundation of RNAi-mediated insect resistance in crops. The RNAi technology came into the limelight when two reports regarding insect control occurred in the scientific community. 
Mao et al. [117] developed transgenic lines of Arabidopsis and tobacco plants expressing CYP6AE14- specific dsRNA. In cotton worm, this gene confers resistance against gossypol, a polyphenol compound. When cotton bollworm larvae fed on leaves of transgenic lines, they showed sensitivity against gossypol in an artificial diet. Baum et al. [118] developed transgenic maize lines resistant to western corn rootworm by expressing dsRNA specific to the gene encoding the A subunit of V-type ATPase pump. Thus, these results suggested that the RNAi pathway can be exploited to control pests from harming the plants by targeting the significant gene of insects. V-type ATPase subunit-A coding genes were also used crucial to develop resistance against the whitefly (B. tabaci) population in tobacco plants [119]. Likewise, RNAi-mediated whitefly (B. tabaci)-resistant transgenic lines of lettuce (Lactuca sativa) targeting V-ATPase transcripts in the whitefly increased the mortality rate of insects feeding on transgenic plants from 83.8-98.1\% [71].

Wang et al. [120] reported that 3-hydroxy-3-methyl glutaryl coenzymeA reductase (HMG-CoA reductase, HMGR) is a significant enzyme in the insect mevalonate pathway and can be utilized as a potential target to produce insect-resistant cultivars using RNAi. Similarly, the chitinase (HaCHI) gene important for molting in insects can also be used as a target to produce insect-resistant plants. Through host-induced RNAi, Helicoverpa armigera-resistant transgenic tobacco and tomato plants were developed [69].

\subsubsection{Abiotic Stress Tolerance}

Plants in their natural field conditions constantly get exposed to various abiotic factors such as high salinity, variation in temperature, flood, drought, and heavy metals, which hinders proper growth and development in plants. These factors are also one of the major causes behind huge crop losses globally. The changing climatic conditions and rapidly expanding population demand creates an urgent need to develop more stress-tolerant cultivars. Hence, RNA interference technology can be exploited to develop transgenic cultivars that can cope with different abiotic stresses. Functional genomics studies revealed that novel genetic determinants are involved in stress adaptation in plants, which can be employed to attain stress tolerance [121].

The receptor for activated C-kinase 1(RACK-1) is a highly conserved scaffold protein that plays a significant role in plant growth and development. RNAi-mediated downregulation of $R A C K-1$ gene in transgenic $O$. sativa plants has shown more tolerance to drought stress as compared to the non-transgenic $O$. sativa plants [122]. Likewise, disruption of $O$. sativa farnesyltransferase/squalene synthase (SQS) by maize squalene synthase via RNAi resulted in enhanced drought tolerance at the vegetative and reproductive stages [123].

Stress tolerance and development in plants are regulated by miRNA, also negatively affecting the expression of the post-transcriptional gene. Wang et al. [124] examined that miRNAs are involved in the very early stage during seed germination and identified that miRNA-mediated regulation of gene expression is present in maize imbibed seed. Wang et al. [125] reported 32 known members of 10 miRNA families and 8 new miRNAs/new members of known miRNA families that were found to be responsive to drought stress by high-throughput sequencing of small RNAs from Medicago truncatula. These findings suggest the importance of miRNAs in the response of plants to abiotic stress in general and drought stress in particular.

OsTZF1 is a member of the CCCH-type zinc finger gene family in rice (O. sativa). Conditions like drought, high-salt stress, and hydrogen peroxide can induce the expression of OsTZF1. Expression of OsTZF1 gene was also induced by abscisic acid, methyl jasmonate, and salicylic acid. The OsTZF1 gene overexpressed in transgenic plants showed enhanced tolerance to high salt and drought stresses, whereas transgenic O. sativa plants in OsTZF1 gene silenced using RNAi technology has shown less tolerance. This suggests the role played by OsTZF1 gene in abiotic stress tolerance [126].

Dehydrin proteins play a significant role in protecting plants from osmotic damage. Various research results suggest that the overexpression of the dehydrin gene WZY2 pro- 
vides more tolerance for plants against osmotic stress. A study conducted by Yu et al. [127] suggests that RNAi-mediated silencing of the WZY2 gene in A. thaliana makes plants intolerant to osmotic stress.

\subsubsection{Seedless Fruit Development}

Seedless fruits are generally appreciated by the consumers as seedlessness increases the quality of fruit with the enhancement of shelf life $[128,129]$. Seedless fruits can be obtained by parthenocarpy, which involves the development of fruit directly from the ovary without fertilization. In eggplant, seedlessness prevents browning and texture reduction of pulp [130]. The production of seedless fruits can be induced artificially by disrupting the genes involved in the formation process of seed and seed set. The seed formation process is regulated by the phytohormones both temporally and spatially. Generally, seedless fruit obtained by inducing mutation or alteration in phytohormones shows pleiotropic effects i.e., change in taste, reduced fruit size, etc. Hence, for the production of parthenocarpic fruits, novel methods with more efficiency should be employed [130]. It has been shown that seed development in fruits limits the yield in cucumber [131,132] and tomato [133]. Thus, the replacement of seed and seed cavities with edible fruit tissue is highly desirable and appreciated by consumers, breeding companies, and production companies. Auxin response factors (ARFs) encode transcription factors that control auxin-dependent plant developmental processes. ARF7 factor of tomato (S. lycopersicum) designated as SIARF7 was found to be highly expressed in unpollinated mature ovaries. Further research revealed that the expression of slARF7 remains high from the initial period of flower development to the formation of mature flowers and decreases within $48 \mathrm{~h}$ after pollination. RNAi-mediated development of transgenic tomato lines with a downregulated slARF7 gene resulted in the generation of parthenocarpic fruits [134]. Schijlen et al. [135] developed seedless tomatoes through RNAi-mediated suppression of the chalcone synthase (CHS) gene, the first gene used in the flavonoid synthesis pathway. Likewise, post-transcriptional gene silencing of the flavonol synthase (FLS) gene, a vital enzyme for flavonols production, resulted in the generation of seedless or less-seeded fruits in tobacco (N. tobacum cv xanthi) [136].

Aucsia genes are distinctly expressed in auxin biosynthesis parthenocarpic flower buds of tomato. The silencing of these genes by RNA interference resulted in parthenocarpic fruit development in tomato with some other auxin-related phenotypes [137]. Takei et al. [138] isolated and characterized small parthenocarpic fruit and flower (spff) mutants in a tomato cultivar. Linkage analysis and RNAi-based silencing of the Solyco4g077010 gene, which encodes the receptor-like protein kinase, resulted in impaired male sterility with parthenocarpic fruit set development.

\subsubsection{Shelf-Life Enhancement}

Fruits and vegetables are more vulnerable to spoilage as compared to cereals because of their nature and composition. Despite being one of the leading producers of fruits and vegetables, India faces massive losses due to post-harvest mishandling, spoilage, and pest invasion during storage and transportation. Hence, it is essential to augment the shelf-life of fruits and vegetables to minimize horticultural losses. This can be achieved by delaying the ripening of the fruit by regulating ethylene biosynthesis, ethylene-mediated signaling, and ethylene response elements with the aid of RNAi. In contrast to other phytohormones, ethylene is the gaseous hormone that plays a major role in the process of fruit ripening through a cascade of signals. 1-Aminocyclopropane-1-carboxylate (ACC) oxidase is an enzyme that catalyzes the biosynthesis of ethylene from its precursor ACC. Tomato transgenic lines with enhanced shelf life have been developed by RNAi-facilitated suppression of ACC oxidase enzyme [139]. Similarly, the expression of three homologs of 1-Aminocyclopropane-1-carboxylate synthase (ACS) was suppressed during the period of ripening in tomato fruits, thereby leading to the production of delayed ripening tomato fruits due to the inhibition of ethylene production [140]. Meli et al. [141] have identified and targeted two ripening-specific $\mathrm{N}$-glycoprotein modified genes, $\alpha$-mannosidase ( $\alpha$-Man) 
and $\beta$-D-N-acetylhexoaminidase $(\beta-H e x)$, and their suppression via RNAi resulted in fruit softening with an extended shelf life.

The SISGR1 gene encodes for the STAY GREEN protein, which regulates fruit color development and ripening by altering ethylene signal transduction in tomatoes. Fruit shelflife was found to be extended in SISGR1-gene-suppressed transgenic tomato lines [142]. Repression of two banana E class (SEPALLATA3) MADS box genes, i.e., MaMADS1 and MaMADS2, through RNAi resulted in transgenic bananas (Musa ascuminata) having desirable characteristics such as delayed color development, reduced fruit softening, delayed ripening and extended shelf-life [143]. Yang et al. [144] reported 22 individual pectate lysase genes in tomato, out of which one pectate lysase gene, i.e., SIPL, has been found to be dominantly expressed during fruit maturation. RNA interference studies of SIPL revealed that it plays a significant role in the enhancement of fruit firmness, pathogen resistance, and prolongation of shelf life. Similarly, carotenoid and flavonoid content in tomatoes was increased by knocking down the endogenous photomorphogenesis regulatory gene DET1 using RNAi [145]. The phenomenon of accumulation of sucrose and other reducing sugars in potato tubers during storage at low temperatures is called 'cold sweetening'. In potato tubers, sugar phosphatase (SPP) plays a significant role in carbohydrate metabolism at room temperature. Downregulation of the SPP gene through RNAi leads to inhibition of cold-induced hexogenesis in transgenic tubers [146].

\subsubsection{Male Sterile Plants Development}

The development of hybrid cultivars has augmented productivity due to hybrid vigor and improved uniformity. Hybrid production depends on the development of male sterility in one parent to ensure purity in hybrids for further production of hybrid seeds. Several methods involving conventional as well as genetic engineering has been reported for the production of male-sterile plants; however, RNAi has turned out to be one of the most efficient tools in the development of male sterile lines by targeting male-specific genes that participate in tapetum and pollen development. In tobacco plants, TA29, a male-specific gene expressed in anthers during microspore development has been targeted using RNAi technology, giving rise to transgenic male sterile lines [147]. Likewise, the downregulation of the Bcp1 gene of $A$. thaliana expressed in both diploid tapetum and haploid microspore resulted in the generation of transgenic male-sterile plants [148]. Sadenosylmethionine decarboxylase (SAMDC) is considered a significant enzyme in the biosynthesis of polyamines in tomato plants. Suppression of SAMDC gene in the tapetal tissue of tomato plants leads to the development of male sterility [149].

Cytoplasmic male sterility is the maternally inherited phenomenon present in plants. Nuclear genes play a crucial role in the rearrangement of mitochondrial DNA, which is found to be associated with the naturally occurring phenomenon of cytoplasmic male sterility during plant development. Suppression of Msh-1-a nuclear gene in tobacco and tomato plants-resulted in reproducible mitochondrial DNA rearrangement with male-sterility [150].

\subsubsection{Flower Color Modification}

Floriculture or flower farming is a field of horticulture that deals with flowers and ornamental plant cultivation. Nowadays, the demand for flowers in different colors and patterns has increased for the purpose of decoration and scents. This can be achieved by silencing the pigment encoding genes using RNA interference technology. A cDNA encoding the chalcone isomerase (CHI) gene isolated from petals of $\mathrm{N}$. tobacum was suppressed using RNAi, thus reducing pigmentation and altering flavonoid components in flower petals [151]. Similarly, flower color alteration in liliaceous ornamental Tricyrtis sp. has been reported using the RNAi construct TrCHS1 targeting chalcone synthase (CHS) [152]. RNAi-facilitated suppression of three anthocyanin biosynthetic genes, chalcone synthase $(C H S)$, anthocyanidin synthase (ANS), and flavonoid $3^{\prime}, 5^{\prime}$-hydroxylase $\left(F 3^{\prime} 5^{\prime} H\right)$, led to changes in flower color of ornamental gentian plants [153]. Naturally, the flower of gentian plants is vivid blue in color. The accumulation of a polyacrylate delphinidin 'gentiodelphin' 
in the petals of gentian plants contribute to the flower color. Anthocyanin 5,3'-aromatic acyltransferase $\left(5 / 3^{\prime} \mathrm{AT}\right)$ and flavonoid $3^{\prime}, 5^{\prime}$-hydroxylase $\left(\mathrm{F}^{\prime} 5^{\prime} \mathrm{H}\right)$ are crucial enzymes for gentiodelphin biosynthesis and their downregulation via RNAi causes modification in flower color [154].

He et al. [155] experimented to rebuild the delphinidin pathway, for which they first identified two cultivars of chrysanthemum and isolated seven anthocyanin biosynthesis genes, namely $\mathrm{CmCHS}, \mathrm{CmF3H}, \mathrm{CmF3}^{\prime} \mathrm{H}, \mathrm{CmDFR}, \mathrm{CmANS}, \mathrm{CmCHI}$, and $\mathrm{Cm} 3 \mathrm{GT}$. Furthermore, the overexpression of the Senecio cruentus $F 3^{\prime} 5^{\prime} H(P C F H)$ gene and suppression of the $\mathrm{CmF}^{\prime} \mathrm{H}$ gene in chrysanthemum resulted in increased cyanidin content with brighter red flower petals, but the accumulation of delphinidin has not been reported.

\subsubsection{Nutritional Improvement}

Plants serve as the major source of required nutrients in the human diet. However, more than two-thirds of the world's population is deficient in one or more essential mineral elements [156]. RNAi can be employed to achieve the required levels of nutrients in crops by modifying various biochemical and physiological pathways. Omega-3 fatty acid desaturase (FAD3) enzyme catalyzes the synthesis of $\alpha$-linolenic acid (18:3) in the polyunsaturated fatty acid synthesis pathway. $\alpha$-linolenic acid is responsible for instability in soybean (Glycine max) and other seed oils. Flores et al. [157], through siRNA-mediated silencing of FAD3 in soybeans, significantly decreased the level of $\alpha$-linolenic acid by $1-3 \%$ as compared to other non-transgenic lines. In Camelina sativa, the oilseed quality has been improved by downregulating the fatty acyl-ACPthioesterase (FATB) gene using artificial miRNA (amiFATB). The results showed a considerable decrease in total saturated fatty acids content with a $45 \%$ reduction in palmitic acid (16:0) and a $38 \%$ reduction in stearic acid (18:0) as compared to wild-type seeds [158].

Kusaba et al. [159] generated an O. sativa cultivar with low glutenin content (named as LGC-1) through the silencing of the gluB gene using hairpin RNA. A high amylose content Triticum cultivar has been produced by suppressing the expression of two starch branching enzyme (SBE) II (namely SBEIIa and SBEIIb) in Triticum endosperm using RNAi [160]. In plants, starch phosphorylation and starch dephosphorylation act as crucial components in the starch degradation process. Downregulation of glucan water dikinase (GWD) and phosphoglucan phosphatase (SEX4) through RNAi resulted in the accumulation of starch in leaves of A. thaliana and Z. mays [161]. Carotenoid content in Brassica napus was elevated by RNA-mediated silencing of $\varepsilon$-Cyclases ( $\varepsilon$-CYC). Seeds obtained by RNAi transgenic Brassica lines were found to be rich in $\beta$-carotene, zeaxanthin, lutein, and violaxanthin [162].

RNAi can also be employed for the accumulation of minerals in crops. Aggarwal et al. [163], through RNAi-mediated downregulation of inositol pentakisphosphate kinase (IPK1), produced Triticum grains with high $\mathrm{Zn}$ and Fe content with a reduced level of antinutrient phytic acid (PA).

\subsubsection{Secondary Metabolite Production}

Plant secondary metabolites are used in fragrances, drugs, food additives, pigments, and pesticides. Biosynthesis of secondary metabolites is regulated by an array of multiple genes, but sometimes it may get obstructed by certain undesirable compounds. RNAi can be used as an effective approach to suppress the expression of those compounds as well as for secondary metabolite manipulation [164]. Allen et al. [165] reported the replacement of morphine with non-narcotic alkaloid (S)-reticuline in the opium poppy (Papaver somniferum) through RNAi-mediated silencing of multiple genes participating at different steps in a complex biochemical pathway. They constructed hpRNA for suppressing the expression of all the members of the codeine reductase (COR) gene family. This led to the development of transgenic lines consisting of (S)-reticuline, a non-narcotic alkaloid precursor, by replacing morphine, codeine, and opium.

Caffeine acts as a natural stimulant for the central nervous system, respiratory system, and circulatory system. It also lessens the risk of liver cancer, mouth, and throat cancer. 
Besides this, its excess intake may cause some health issues such as insomnia, nervousness, an upset stomach, restlessness, and muscle tremors. In coffee plants, three enzymes participate in the caffeine biosynthesis viz. CaXMT1, CaMXMT1 (theobromine synthase), and CaDXMT1 (caffeine synthase). The RNAi-mediated silencing of the CaMXMT1 gene resulted in a 70\% decrease in caffeine content, indicating RNAi technology can be employed for the production of decaffeinated coffee beans [166]. Similarly, low-caffeine-contentcontaining tea (Camellia sinensis) transgenic lines were developed by downregulating the caffeine synthase (CS) gene using RNAi [167].

Salvia miltiorrhiza is a famous Chinese herb, also used in other Asian countries. The production of phenolic acid was enhanced by downregulating the initial enzyme in flavonoid biosynthesis, i.e., the Chalcone synthase (CHS) gene with elicitor treatment of salicylic acid. Results showed a considerable decrease in flavonoid production with an increase in phenolic acid content [168]. In several aromatic plants such as spearmint (Mentha spicata), tiny, specialized structures are present for secondary metabolite production called peltate glandular trichomes (PGT). Wang et al. [169] examined the role of transcription factors in the secondary metabolite biosynthesis pathway, for which they isolated and functionally characterized a MsYABBY5 gene expressed in PGT. The production of terpenes was increased after the suppression of the $M s Y A B B Y 5$ gene, suggesting that encoded transcription factors act as a negative regulator for secondary metabolite production.

In papaya (Carica papaya L.) plants, the DE-ETIOLATED-1 (DET1) gene, which is a negative regulator of photomorphogenesis, was suppressed through RNAi in embryonic callus to study its effects on the expression of a gene involved in the biosynthesis pathway of secondary metabolites, with results suggesting a relationship between the photo-regulated pathway and secondary metabolite synthesis [170].

\section{Clustered Regularly Interspaced Short Palindromic Repeat (CRISPR)/CRISPR-Associated Protein (CRISPR/Cas)}

Until 2013, the zinc-finger nucleases (ZFNs) and transcription activator-like effector nucleases (TALENs) were used as the most prevalent gene-editing tools [171-173]. These methods of gene editing rely on the use of specific DNA recognition and binding properties of specialized proteins viz. customized homing nuclease (meganuclease), zinc-finger nucleases (ZFNs), and transcription activator-like effector nucleases (TALENs). These nucleases are fusion products of domains derived from zinc finger transcription factors or transcription activator-like effectors formulated to identify almost any DNA sequence and the endonuclease domain of class II restriction enzyme, which can introduce doublestranded breaks (DSBs) [174]. CRISPR (Clustered Regularly Interspaced Short Palindromic Repeats) and the CRISPR-associated protein-9 (Cas9) nuclease system came out as a viable tool for targeted gene editing in plants [175]. In the last decade, the CRISPR/CAS system has made great achievements in many fields owing to its targeting, efficiency, versatility, and simplicity (Figure 3). 


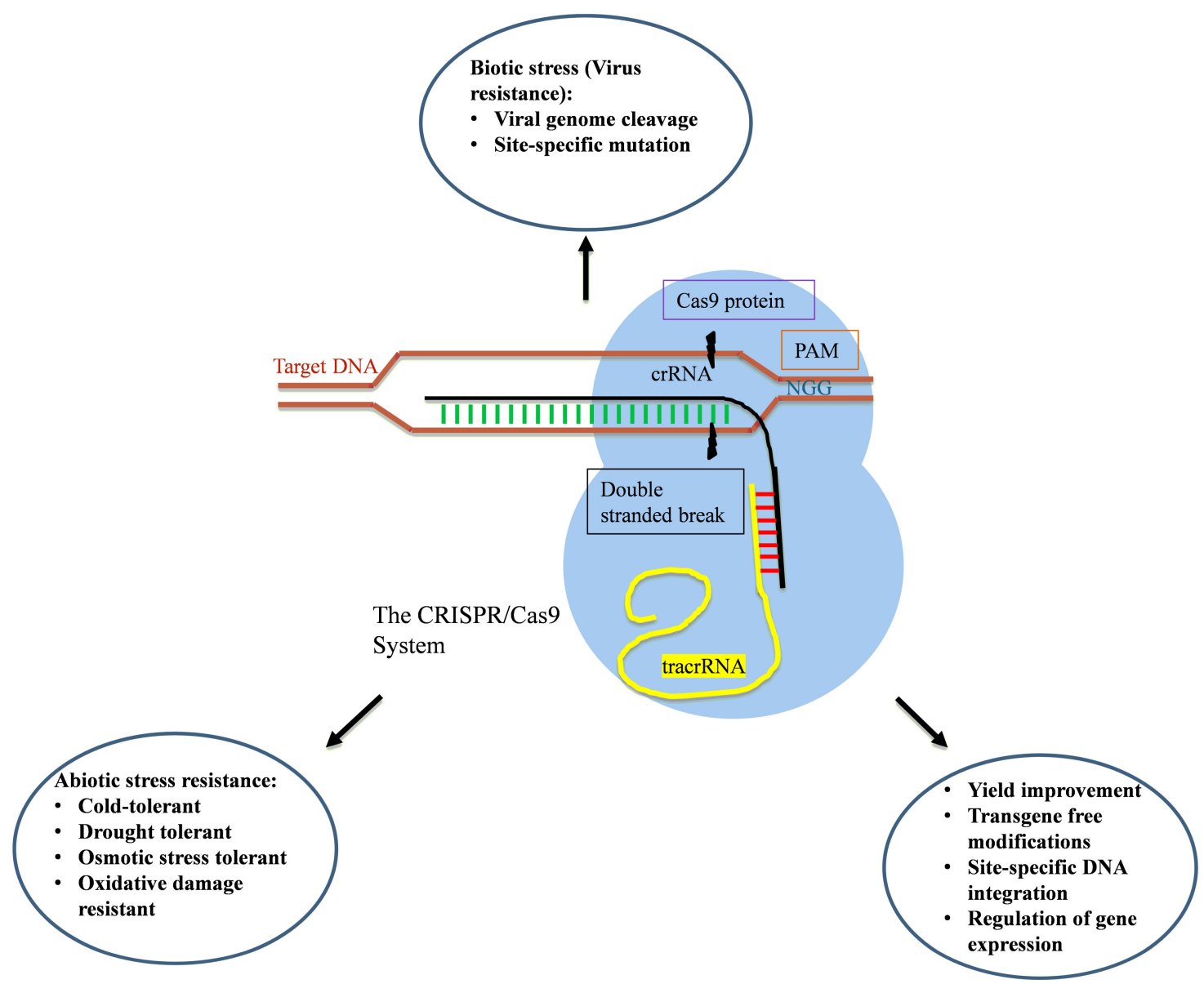

Figure 3. Applications of the CRISPR/Cas9 system in crop improvement. Here, the omission of undesirable traits and the adjunction of purposeful traits occurs through highly specific targeted genome modification.

CRISPR comprises a DNA fragment with short palindromic repeats that are interspaced by the short sequences of variable length regarded as 'non-repetitive' elements or spacers. The CRISPR assembly was first recognized in the genome of Escherichia coli in 1987 [176]. The functional relationship between the CRISPR locus and adjacently located CRISPR-associated (Cas) genes was identified later [177]. The biological function of the CRISPR/Cas system was, however, unknown until 2015. A quantum leap came in the gene-editing technology with the findings that variable spacer sequences are derived from the foreign genome of virus and plasmid, suggesting the role of the CRISPR/Cas system as part of the adaptive immunity in prokaryotes [178-180]. The immunity is acquired by the acquisition of short DNA segments of invading viruses and plasmids in between the adjacent repeats as spacers. The CRISPR/Cas system provides immunity by utilizing the RNA-guided nucleases to cleave the genome of invaders in a sequence-specific manner. This was experimentally confirmed in 2007, i.e., phage-resistant bacteria have integrated spacers similar to the nucleic acid sequence of bacteriophage and the phage-resistant phenotype can be altered by the insertion or deletion of particular spacers. This implies that CRISPR, in association with Cas genes, could participate in providing immunity against viruses and plasmids [181]. The motifs associated with spacer precursor (proto-spacers) from the genome of invading viruses were identified at the time of the spacer uptake mechanism. These short stretches of di- or trinucleotides, which usually have sequence $5^{\prime}$-NGG$3^{\prime}$ and exceptionally $5^{\prime}$-NAG-3' present at one position downstream to proto-spacers, were named proto-spacers adjacent motifs (PAMs). These motifs (PAMs) play a key role in the identification of proto-spacers as well as assuring the correct integration of spacers in between repeated arrays of CRISPR $[178,182,183]$. Specificity is provided by the 'Seed Sequence' present approximately $12 \mathrm{bp}$ upstream of PAM, which must be complementary 
to the RNA. Brouns et al. [184] revealed that a long-transcript CRISPR RNA precursor (pre-crRNA) is produced by transcription of the CRISPR locus, which further processed into a mature crRNA molecule, which serves as single guide RNA (sgRNA). Each crRNA molecule consists of spacers, which are flanked by short DNA repeats, and this crRNA combines with transactivating CRISPR RNA (tracr RNA), which stimulate Cas9 and mediates the antiviral response. In 2010, it was experimentally proved that the CRISPR1/Cas system of Streptococcus thermophiles naturally uptakes spacers from a self-replicating plasmid containing antibiotic-resistant genes, provided to select transformed bacteria. They also examined in vivo that CRISPR1/Cas creates double-stranded breaks at specific sites within proto-spacers, suggesting the molecular basis of CRISPR/Cas system-mediated adaptive immunity [185]. As compared to ZFNs and TALENs, the construction of the CRISPR/Cas system is easier as it consists of just a Cas9 protein and a synthetic single-guide RNA (sgRNA), which needs to be designed complementarily to the target DNA sequence.

\subsection{Mechanism of Action}

Makarova et al. [186] classified the CRISPR/Cas system into three distinct polythetic classes, named Type I, II, and III. Cas1 and Cas2 serve as a vital constituent of all three systems as they play a crucial role in the integration of spacers in between the repeated array of CRISPR. Each system consists of its signature proteins and depends on these proteins to generate an immune response against the invading virus or plasmid [187]. In summary:

1. Type I systems contain signature protein Cas3 that consists of both helicase and DNase domains for the degradation of target [188]. Recently, six subtypes of the type I system (Subtype I-A to I-F) have been identified to contain a variable number of Cas proteins. Aside from Cas proteins, the type I system also encodes for the CRISPR-associated complex for the antiviral defense (Cascade) complex, and Cas3 is also the part of this complex.

2. Type II encodes three signature proteins, viz. Cas1, Cas2, and Cas9, and sometimes a fourth protein, i.e., Csn2 and Cas4. Cas9 is a multifunctional protein that plays a crucial role in the Type II system in adaptation to the degradation of the target along with trans-encoded small RNA (tracr RNA) $[4,185,189,190]$. Three subtypes of the type II system have been discovered, namely type II-A, type II-B, and type II-C [191,192].

3. Type III is defined by the presence of Cas10, whose function is still unclear. Two subtypes of the type III system (type III-A and type III-B) have been identified [193].

Type I and II systems target DNA degradation, but exceptionally, the type III system targets DNA as well as RNA. The most widely used system is the type II CRISPR/Cas9 system from Streptococcus pyogenes [4]. Until now, the type II system has been studied in bacteria but type I and type III systems have marked their presence in both bacteria and archaea [186]. The general mechanism of action of the CRISPR/Cas system involves three stages, i.e., adaption, expression, and interference. The proteins involved in the adaption stage (namely, Cas1 and Cas2) are highly conserved, whereas in expression and interference stages, the proteins vary greatly between the organisms. Each stage details are given below:

1. Adaption stage: The short pieces of DNA homologous to the genomic sequence of the invading virus or plasmid get incorporated at the leader side of the CRISPR locus. A new spacer unit is created by the duplication of repeats at every integration step. In type I and III CRISPR/Cas systems, the selection of proto-spacers occur by the recognition of PAMs present on or near the location of proto-spacers of the invading genetic element $[183,194,195]$. After the recognition, Cas1 and Cas2 proteins help in the integration of proto-spacers in between the repeat arrays of CRISPR.

2. Expression stage: At this stage, the expression of the spacer takes place via transcription of the CRISPR locus and leads to the generation of a long transcript of pre-CRISPR RNA (pre-crRNA), which is processed into short crRNA by endoribonucleases. In the type I CRISPR/Cas system, pre-crRNA binds with the CRISPR-associated complex for 
the antiviral defense (Cascade) complex, processed into crRNA by cleavage through Cas6e and Cas6f. The crRNA produced has an 8-nt repeat fragment at the $5^{\prime}$ end and the fragment left forms the hairpin structure on the $3^{\prime}$ end. In the type II CRISPR/Cas system, a repeated fragment of pre-crRNA pairs with the trans-encoded small RNA (tracer RNA), which is further cleaved by RNase III in the presence of Cas9 [189]. Consequently, cleavage at a fixed distance in spacers may lead to maturation. The type III system uses the Cas6 protein for processing to crRNA, but afterward, crRNA is transferred to a different complex of Cas proteins, namely Csm in subtype III-A systems and Cmr in Subtype III-B. Further, cleavage occurs at the $3^{\prime}$ end in subtype III-B subsystems [196].

3. Interference stage: After the expression, invading DNA or RNA is targeted and cleaved within proto-spacer sequences. The crRNA acts as a single guide RNA and guides the Cas protein towards the complementary target sequences of the invading genome of the virus or plasmid. In type I systems, the Cascade complex is guided by crRNA towards complementary target DNA, and invading DNA possibly cleaved by Cas3 protein. The Cas9 protein loaded with crRNA cleaves the target DNA in type II systems. The subtype of the type III system, III-A systems, target DNA [194] whereas III-B systems target RNA [196].

\subsection{Applications}

Progression of the CRISPR/Cas system from a biological defense phenomenon to a gene-editing tool came into light when it was revealed that the genome sequence can be remodeled by simply modifying the 20nt in the crRNA, and fusing it with tracr RNA to make a single chimeric guide RNA (gRNA). This led to the reduction of the threecomponent system to a two-component CRISPR/Cas system [4]. Unlike the Cas3 protein, which degrades the target completely, Cas 9 introduces single double-stranded breaks (DSBs) in DNA, which is a salient feature to be an efficient gene-editing tool. DSBs induced in DNA triggers the DNA repair pathways in the cell, and CRISPR/Cas9 manipulates these pathways to alter the genome. Two main pathways are involved in the DNA repair, viz. non-homologous end joining (NHEJ) and homology-directed repair (HDR). NHEJ is more error-prone as while the cuts, insertion, or deletion (InDels) mutation may take place, gene knock-out of mutation occurs in the coding region or the production of a cripple gene product. HDR utilizes another piece of DNA homologous to target DNA to repair DSBs. As in HDR, the incorporation of a DNA element takes place through recombination, so any kind of insertion, deletion, or alteration in the sequence can be done [197,198]. Offtarget cleavage can be avoided by selecting unique target sites adjacent to PAM [4]. These approaches have previously been studied using ZFNs and TALENs, but comparatively, Cas9 is simple to construct while it can also target multiple genes simultaneously [197].

Owing to its high efficiency, versatility, and simplicity, the CRISPR/Cas system can be employed for developing new cultivars (Table 2). It has been widely used in many plants such as A. thaliana, N. benthamiana, O. sativa, and S. tuberosum $[199,200]$. 
Table 2. CRISPR/Cas9 system-mediated gene editing in crops.

\begin{tabular}{|c|c|c|c|}
\hline Trait(s) & Crop Used & Targeted Gene(s) & References \\
\hline Drought tolerance & Z. mays (Maize) & ARGOS8 & [201] \\
\hline Turnip mosaic virus (TMV) resistance & A. thaliana & eIF (iso) $4 E$ & [202] \\
\hline $\begin{array}{l}\text { Cucumber vein yellowing virus (CMYV) } \\
\text { resistance }\end{array}$ & Cucumis sativus & eIF4E & [203] \\
\hline Drought tolerance & S. lycopersicum & SIMAPK3 & [204] \\
\hline Cold tolerance & O. sativa & OsAnn3 & [205] \\
\hline Parthenocarpic fruit development & S. lycopersicum & SIIAA9 & [206] \\
\hline Chilling stress tolerance & S. lycopersicum & SlCBF1 & [207] \\
\hline $\begin{array}{l}\text { Tomato yellow leaf curl virus (TYLCV) } \\
\text { resistance }\end{array}$ & S. lycopersicum, N. benthamiana & Coat protein $(C P)$ Replicase (Rep) & [208] \\
\hline Cauliflower mosaic virus (CMV) resistance & A. thaliana & CaMV CP & [209] \\
\hline Rice tungro spherical virus (RTSV) resistance & \multirow{2}{*}{ O. sativa } & eIF4G & [210] \\
\hline Salt tolerance & & OsRR22 & [211] \\
\hline Male-sterile development & T. aestivum & Ms1 & [212] \\
\hline Heat stress tolerance & S. lycopersicum & SIMAPK3 & [127] \\
\hline Drought and salt stress tolerance & \multirow{2}{*}{ A. thaliana } & $\begin{array}{l}\text { DAP4 } \\
\text { SOD7 }\end{array}$ & [213] \\
\hline Drought tolerance & & AREB1 & [214] \\
\hline Wheat dwarf virus (WDV) resistance & Hordeum vulgare & $\begin{array}{c}C P \\
\text { Rep / Rep4 }\end{array}$ & [215] \\
\hline Yield improvement & B. napus & BnaMAX1 & [216] \\
\hline $\begin{array}{l}\text { Yield improvement } \\
\text { Stress tolerance }\end{array}$ & O. sativa (Nippobare) & $\begin{array}{c}\text { OsPIN5b } \\
\text { GS3 } \\
\text { OsMYB30 }\end{array}$ & [217] \\
\hline Yield improvement & \multirow[t]{2}{*}{ O. sativa } & $\begin{array}{c}\text { Cyt P450 homeologs } \\
\text { OsBADH2 }\end{array}$ & [218] \\
\hline Drought and stress tolerance & & OsDST & [219] \\
\hline $\begin{array}{l}\text { Tomato yellow leaf curl virus (TYLCV) } \\
\text { resistance }\end{array}$ & S. lycopersicum & $\operatorname{rgs} C a M$ & [220] \\
\hline Soyabean mosaic virus (SMV) resistance & Glycine max & $\begin{array}{c}\text { GmF3H1 } \\
\text { GmF3H2 } \\
\text { GmFNSII-1 }\end{array}$ & {$[171]$} \\
\hline
\end{tabular}

\subsubsection{Yield Improvement}

In several plants, seasonal change in day-length may trigger flowering and day-length sensitivity, limiting their geographical range of cultivation. A CRISPR/Cas9-mediated mutation in SPG5, which is a repressor of florigen paralog and flowering, resulted in rapid flowering with enhancement in the compact determinate growth habit of field tomato [221]. Li et al. [222], using the RNA-guided Cas9 system, demonstrated that this technology can be used in vivo as the desired target mutator (DTM) to develop a mutated maize germplasm. For hybrid breeding in crops, photoperiod and thermosensitive genetic male sterility (PGMS and TGMS) are the two main components. To improve the yield potential of $O$. sativa, the development of hybrid $O$. sativa is important. Hybrid O. sativa breeding relies on the two-line system, and the generation of thermo-sensitive genetic male sterility is widely used in this system. TMS5 broadly applied the TGMS gene from China, which was manipulated using the CRISPR/Cas system to develop new 'transgene clean' TGMS lines. Eleven novel cultivars of TGMS were developed in one year, indicating the ability 
of the CRISPR/Cas system to improvieefficiency in hybrid O. sativa breeding [223]. Li et al. [224] employed a CRISPR/Cas gene-editing tool to mutate Gna1, DEP1, GS3, and IPA1 genes of the $O$. sativa cultivar Zhonghua 11, resulted in T2 generation of gna1, dep1, and gs3 mutants showing characteristics such as enhanced grain number, dense erect panicles, and larger grain size, respectively.

\subsubsection{Abiotic Stress Tolerance}

The CRISPR/Cas9 system has enormous potential to generate crops tolerant to abiotic stresses. CRISPR/Cas9-mediated knock-out of the O. sativa annexin gene OsAnn3 led to the development of mutant lines tolerant to cold, thus indicating the involvement of OsAnn3 in cold tolerance of O. sativa [205]. In A. thaliana, C-repeat binding factors (CBFs) play a decisive role in cold-stress tolerance. However, the precise function of these factors is unclear owing to the lack of null cbf triplet mutants. Thus, CRISPR/Cas9 has been employed to produce cbf 1,3 double and cbf $1,2,3$ triple mutants by disrupting $C B F 1$ or $C B F 1 / C B F 2$ in a $c b f 3$ T-DNA insertion mutant [225].

Mitogen-activated protein kinases (MAPK1) signaling molecules play a significant role in drought stress tolerance. In tomato, drought stress causes the accumulation of reactive oxygen species (ROS), which causes oxidative damage in tomatoes. SIMAPK3 mutants generated by CRISPR/Cas gene editing led to more tolerance in the tomato plants [204]. Maize ARGOS8 acts as a negative regulator of ethylene response. New variants of ARGOS8 were developed with a native maize GOS2 promoter through CRISPR/Cas advanced breeding technology for the production of drought-tolerant crops. The field study showed that the ARGOS8 variant of maize has increased grain yield significantly as compared to the wild type under flowering stress-condition [201].

SNF-1 related protein kinases 2 (SnRK2) serve as the main regulator of hyper-osmotic stress signaling and ABA-dependent development in plants. SnRK2 and osmotic stress / ABA activated protein kinase 2 (SAPK2) can be the primary mediator of ABA signaling in O. sativa subclass I and II. Lou et al. [226] examined the functional role of SAPK2 by producing loss-of-function mutants using CRISPR/Cas technology. When drought, high-salinity, and polyethylene glycol (PEG) stresses were given, SAPK2 expression was highly upregulated. The SAPK2 mutants showed an ABA-insensitive phenotype during germination and post-germination stages, suggesting the importance of ABA-mediated seed dormancy. Moreover, it has been observed that SAPK2 increases the tolerance of $O$. sativa plants to salt and PEG stress.

\subsubsection{Biotic Stress Tolerance}

The CRISPR/Cas9 system originally emerged as part of adaptive immunity in bacteria and archaea. Over the past years, it has been explored for targeted gene editing in various plants to provide resistance against biotic stresses. The CRISPR/Cas9 system was used to confer resistance against the Tomato yellow leaf curl virus (TYLCV) in N. benthamiana plants by designing sgRNA consisting of coding and non-coding sequences of TYLCV, resulting in reduced viral DNA accumulation with considerable attenuation in symptoms of infection [227]. Similarly, using the sgRNA-Cas9 system in N. benthamiana beet severe curly top virus (BSCTV) accumulation has also been reduced [228]. Virus-resistant cucumber (Cucumis satious L.) cultivars were developed using the sgRNA-Cas9 system to disrupt the function of the recessive eIF4E gene. Resultant non-transgenic homozygous T3 progenies showed resistance against the Cucumber vein yellowing virus (Ipomovirus) infection, potyviruses such as the Zucchini yellow mosaic virus and the Papaya ringspot mosaic virus-W [203]. Likewise, Pyott et al. [202] employed CRISPR/Cas9 technology to introduce deleterious site-specific mutation in the eIF(iso) $4 E$ locus of $A$. thaliana to develop transgenic lines completely resistant against the Turnip mosaic virus (TuMV), which is a major pathogen for vegetables. These findings suggest that the CRISPR/Cas9 system is an innovative approach to generate potyvirus-resistant, agronomically important crops without incorporating transgenes. Zhan et al. [229] used CRISPR/Cas 13a in potato plants 
to develop resistance against the Potato virus $Y$ (PVY). Reduced accumulation of virus and symptoms was observed in transgenic potato lines.

In $A$. thaliana, the enhanced disease resistance 1 (EDR1) gene acts as a negative regulator of the defense response against powdery mildew. CRISPR/Cas9 technology was employed to develop the Taedr1 Triticum plants by altering the three homeologs of Triticum EDR1. No off-target mutations have been detected in Taedr1 mutants and were found to be resistant to powdery mildew [230].

\section{Conclusions and Future Prospects}

In the 21st century, the foremost task for the agriculture industry is to provide food security to the rapidly expanding population globally. Besides, developing countries are also facing malnutrition. Hence, to ensure an adequate supply of balanced food to the world, there is an urgent need to develop biofortified staple food, vegetables, and fruits, enriched in all the essential compounds and mineral elements. The development of cultivars resistant to biotic stresses and tolerant to abiotic stresses i.e., changing environmental conditions, high temperature, drought, flood, oxidative stresses, high salt concentration, and heavy metal-polluted soil, can be a setback for world food security, malnutrition, and famine problems. The feasibility of using RNAi and CRISPR/Cas9 technology has become a topic of current interest in the last few years (Figure 4). These approaches hold great potential to develop crops with high-value agronomic traits by targeting their broad range of targets, accelerating crop improvement schemes, and increasing their effectiveness.

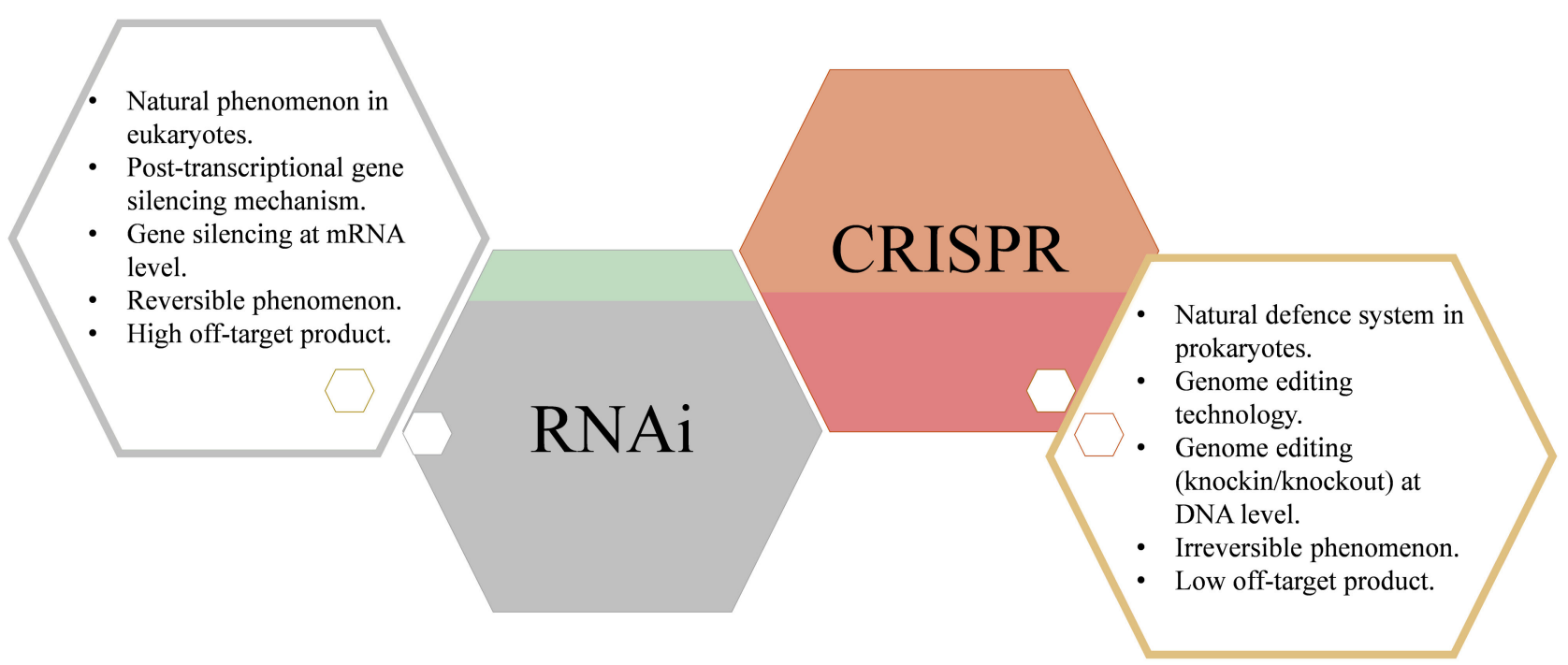

Figure 4. RNA interference vs. the CRISPR/Cas9 system.

Current progress in CRISPR technology has advanced functional genomics research and innovative crop development. The recent technological advancement of CRISPR related to promoter, base editing, and prime editing has enhanced its effectiveness in gene editing for crop improvement [231]. The selection of the promoter for the expression of Cas9 and sgRNAs and the configuration of these expression cassettes are crucial to achieve proficient genome editing. Commonly, there are three expression strategies for the CRISPR-Cas system in plants, i.e., a mixed dual promoter system, a dual Pol II promoter system, and a single transcriptional unit system (STU) [232]. Although the STU system is considered superior over other two systems, it has limitations i.e., refinement of the system, nonoptimal expression system, and difficult post-transcriptional processes [232]. The limitations could be combatted by using a bidirectional promoter system that can initiate transcription in both orientations [233]. The two components (cas9 and sgRNA) are placed on each promoter's end, enabling the opposite direction transcription. Further, the opposite architecture of the construct can help in balancing the expression strength and 
permit independent fine-tuning of the individual cas9 and sgRNA expression cassettes with the use of different enhancers, $3^{\prime}$ UTR, and terminators [234]. Furthermore, 'baseediting', i.e., the newest advancement of CRISPR-Cas-based technology, can be used to directly install point mutations in cellular DNA without inducing a double-strand DNA break [235]. The CRISPR/Cas-based, single-base-pair editing system can overcome limited efficiency and a high rate of undesired insertion or deletion mutations. The CRISPR/Cas base-editing system depends on the two classes of DNA base editors, i.e., adenine and cytosine base-editors, and is capable of conducting all four transition mutations $(\mathrm{C} \rightarrow \mathrm{T}$, $T \rightarrow C, A \rightarrow G$, and $G \rightarrow A$ ) [235]. At present, base-editing is considered as the most effective tool for plant genome editing. However, the base-editing technologies cannot generate precise base-edits beyond the four transition mutations. However, the recent technological evolution of prime editing of the CRISPER/Cas system can overcome the limitations [236]. Prime-editors consist of an engineered reverse transcriptase fused to Cas9 nickase and a prime-editing guide RNA. In prime-editing, a less stringent protospacer-adjacent motif is required due to the varied length of the reverse transcriptase template and no "bystander" editing [237]. However, prime-editing is still in its infancy, and there is a need to study its specificity and potential for off-target modification.

Moreover, both RNAi and CRISPR/Cas will bring a gene revolution in breeding crops with desired traits including quality. These technologies may help in supporting food security in both developed and developing countries. Studies concerned with gene silencing and gene deletion or disruption have also become essential to analyze the gene function in crops that could further help to design better gene-editing strategies.

Author Contributions: M.R., K.C. and M.K. wrote the manuscript and drew the illustrations. A.C., R.O. and V.V. assisted in manuscript writing and editing. N.P. and A.C. conceptualized, supervised, and edited the manuscript. All authors have read and agreed to the published version of the manuscript.

Funding: The research was funded by Swedish Research Council (VR), project \#2018-05179.

Data Availability Statement: Not applicable.

Acknowledgments: Funding support is acknowledged for the project \#2018-05179 from the Swedish Research Council (VR) to A.C. Financial support from Department of Science and Technology (IFA14LSPA-27) and Science and Engineering Research Board (ECR/2018/002633), Government of India to N.P. is also acknowledged.

Conflicts of Interest: The authors declare no conflict of interest.

\section{References}

1. Godfray, H.C.J.; Beddington, J.R.; Crute, I.R.; Haddad, L.; Lawrence, D.; Muir, J.F.; Pretty, J.; Robinson, S.; Thomas, S.M.; Toulmin, C. Food Security: The Challenge of Feeding 9 Billion People. Science 2010, 327, 812-818. [CrossRef] [PubMed]

2. Chen, K.; Wang, Y.; Zhang, R.; Zhang, H.; Gao, C. CRISPR/Cas Genome Editing and Precision Plant Breeding in Agriculture. Annu. Rev. Plant Biol. 2019, 70, 667-697. [CrossRef]

3. Pathak, K.; Gogoi, B. RNA interference (RNAi): Application in crop improvement: A review. Agric. Rev. 2016, 37, 245-249. [CrossRef]

4. Jinek, M.; Chylinski, K.; Fonfara, I.; Hauer, M.; Doudna, J.A.; Charpentier, E. A Programmable dual-RNA-guided DNA endonuclease in adaptive bacterial immunity. Science 2012, 337, 816-821. [CrossRef] [PubMed]

5. Pardo, B.; Gómez-González, B.; Aguilera, A. DNA Repair in Mammalian Cells. Cell. Mol. Life Sci. 2009, 66, 1039-1056. [CrossRef]

6. Gill, R.A.; Scossa, F.; King, G.J.; Golicz, A.; Tong, C.; Snowdon, R.J.; Fernie, A.R.; Liu, S. On the Role of Transposable Elements in the Regulation of Gene Expression and Subgenomic Interactions in Crop Genomes. Crit. Rev. Plant Sci. 2021, 40, 157-189. [CrossRef]

7. Mamta, B.; Rajam, M.V. RNA Interference: A Promising Approach for Crop Improvement. In Biotechnologies of Crop Improvement; Gosal, S., Wani, S., Eds.; Springer: Cham, Germany, 2018; Volume 2, pp. 41-65. [CrossRef]

8. Napoli, C.; Lemieux, C.; Jorgensen, R. Introduction of a Chimeric Chalcone Synthase Gene into Petunia Results in Reversible Co-Suppression of Homologous Genes in trans. Plant Cell 1990, 2, 279-289. [CrossRef]

9. Fire, A.; Xu, S.; Montgomery, M.K.; Kostas, S.A.; Driver, S.E.; Mello, C.C. Potent and specific genetic interference by doublestranded RNA in Caenorhabditis elegans. Nature 1998, 391, 806-811. [CrossRef] 
10. Johnson, N.; Axtell, M.J. Small RNA warfare: Exploring origins and function of trans-species microRNAs from the parasitic plant Cuscuta. Curr. Opin. Plant Biol. 2019, 50, 76-81. [CrossRef] [PubMed]

11. Dutta, T.K.; Banakar, P.; Rao, U. The status of RNAi-based transgenic research in plant nematology. Front. Microbiol. 2015, 5, 760. [CrossRef] [PubMed]

12. Lunardon, A.; Johnson, N.; Hagerott, E.; Phifer, T.; Polydore, S.; Coruh, C.; Axtell, M.J. Integrated annotations and analyses of small RNA-producing loci from 47 diverse plants. Genome Res. 2020, 30, 497-513. [CrossRef]

13. Lunardon, A.; Kariuki, S.M.; Axtell, M.J. Expression and processing of polycistronic artificial microRNAs and trans -acting siRNAs from transiently introduced transgenes in Solanum lycopersicum and Nicotiana benthamiana. Plant J. 2021, 106, 1087-1104. [CrossRef]

14. Yang, X.; Sanchez, R.; Kundariya, H.; Maher, T.; Dopp, I.; Schwegel, R.; Virdi, K.; Axtell, M.J.; MacKenzie, S.A. Segregation of an MSH1 RNAi transgene produces heritable non-genetic memory in association with methylome reprogramming. Nat. Commun. 2020, 11, 1-17. [CrossRef]

15. Romano, N.; Macino, G. Quelling: Transient inactivation of gene expression in Neurospora crassa by transformation with homologous sequences. Mol. Microbiol. 1992, 6, 3343-3353. [CrossRef]

16. Wilson, R.C.; Doudna, J.A. Molecular Mechanisms of RNA Interference. Annu. Rev. Biophys. 2013, 42, 217-239. [CrossRef]

17. Cerutti, H.; Ma, X.; Msanne, J.; Repas, T. RNA-mediated silencing in algae: Biological roles and tools for analysis of gene function. Eukaryot. Cell 2011, 10, 1164-1172. [CrossRef]

18. Hammond, S.M.; Bernstein, E.; Beach, D.; Hannon, G.J. An RNA-directed nuclease mediates post-transcriptional gene silencing in Drosophila cells. Nat. Cell Biol. 2000, 404, 293-296. [CrossRef] [PubMed]

19. Elbashir, S.M.; Harborth, J.; Lendeckel, W.; Yalcin, A.; Weber, K.; Tuschl, T. Duplexes of 21-nucleotide RNAs mediate RNA interference in cultured mammalian cells. Nat. Cell Biol. 2001, 411, 494-498. [CrossRef] [PubMed]

20. Ali, N.; Datta, S.K.; Datta, K. RNA interference in designing transgenic crops. GM Crop 2010, 1, 207-213. [CrossRef] [PubMed]

21. Hammond, S.M. Dicing and slicing: The core machinery of the RNA interference pathway. FEBS Lett. 2005, 579, 5822-5829. [CrossRef] [PubMed]

22. Hutvagner, G.; Simard, M. Argonaute proteins: Key players in RNA silencing. Nat. Rev. Mol. Cell Biol. 2008, 9, 22-32. [CrossRef] [PubMed]

23. Redfern, A.D.; Colley, S.M.; Beveridge, D.J.; Ikeda, N.; Epis, M.R.; Li, X.; Foulds, C.E.; Stuart, L.M.; Barker, A.; Russell, V.J.; et al. RNA-induced silencing complex (RISC) Proteins PACT, TRBP, and Dicer are SRA binding nuclear receptor coregulators. Proc. Natl. Acad. Sci. USA 2013, 110, 6536-6541. [CrossRef]

24. Dash, S.K.; Sushil, K.M.; N, M.H. RNA Interference a fine tuner of gene regulation: A review. Int. J. Biotechnol. Mol. Biol. Res. 2015, 6, 35-39. [CrossRef]

25. Zhang, H.; A Kolb, F.; Jaskiewicz, L.; Westhof, E.; Filipowicz, W. Single Processing Center Models for Human Dicer and Bacterial RNase III. Cell 2004, 118, 57-68. [CrossRef] [PubMed]

26. Aalto, A.P.; E Pasquinelli, A. Small non-coding RNAs mount a silent revolution in gene expression. Curr. Opin. Cell Biol. 2012, 24, 333-340. [CrossRef]

27. Kurihara, Y.; Takashi, Y.; Watanabe, Y. The interaction between DCL1 and HYL1 is important for efficient and precise processing of pri-miRNA in plant microRNA biogenesis. RNA 2006, 12, 206-212. [CrossRef] [PubMed]

28. Kurihara, Y.; Watanabe, Y. From The Cover: Arabidopsis micro-RNA biogenesis through Dicer-like 1 protein functions. Proc. Natl. Acad. Sci. USA 2004, 101, 12753-12758. [CrossRef]

29. Huang, Y.; Ji, L.; Huang, Q.; Vassylyev, D.G.; Chen, X.; Ma, J.-B. Structural insights into mechanisms of the small RNA methyltransferase HEN1. Nat. Cell Biol. 2009, 461, 823-827. [CrossRef]

30. Li, J.; Yang, Z.; Yu, B.; Liu, J.; Chen, X. Methylation protects miRNAs and siRNAs from a 3'-end uridylation activity in Arabidopsis. Curr. Biol. 2005, 15, 1501-1507. [CrossRef]

31. Guo, Q.; Liu, Q.; ASmith, N.; Liang, G.; Wang, M.B. RNA silencing in plants: Mechanisms, technologies and applications in horticultural crops. Curr. Genom. 2016, 17, 476-489. [CrossRef] [PubMed]

32. Huntzinger, E.; Izaurralde, E. Gene silencing by microRNAs: Contributions of translational repression and mRNA decay. Nat. Rev. Genet. 2011, 12, 99-110. [CrossRef] [PubMed]

33. Pareek, M.; Yogindran, S.; Mukherjee, S.K.; Rajam, M.V. Plant MicroRNAs: Biogenesis, Functions, and Applications. In Plant Biology and Biotechnology; Springer: New Delhi, India, 2015; pp. 639-661. [CrossRef]

34. Mello, C.C.; Conte, D. Revealing the world of RNA interference. Nat. Cell Biol. 2004, 431, 338-342. [CrossRef] [PubMed]

35. Bernstein, E.; Caudy, A.; Hammond, S.M.; Hannon, G.J. Role for a bidentate ribonuclease in the initiation step of RNA interference. Nat. Cell Biol. 2001, 409, 363-366. [CrossRef] [PubMed]

36. Hamilton, A.J.; Baulcombe, D.C. A species of small antisense RNA in posttranscriptional gene silencing in plants. Science 1999, 286, 950-952. [CrossRef]

37. Saurabh, S.; Vidyarthi, A.S.; Prasad, D. RNA interference: Concept to reality in crop improvement. Planta 2014, $239,543-564$. [CrossRef]

38. Aoki, K.; Moriguchi, H.; Yoshioka, T.; Okawa, K.; Tabara, H. In vitro analyses of the production and activity of secondary small interfering RNAs in C. elegans. EMBO J. 2007, 26, 5007-5019. [CrossRef] [PubMed] 
39. Halic, M.; Moazed, D. Dicer-Independent Primal RNAs Trigger RNAi and Heterochromatin Formation. Cell 2010, 140, 504-516. [CrossRef]

40. Lee, H.-C.; Li, L.; Gu, W.; Xue, Z.; Crosthwaite, S.K.; Pertsemlidis, A.; Lewis, Z.; Freitag, M.; Selker, E.U.; Mello, C.C.; et al. Diverse Pathways Generate MicroRNA-like RNAs and Dicer-Independent Small Interfering RNAs in Fungi. Mol. Cell 2010, $38,803-814$. [CrossRef]

41. Ye, R.; Chen, Z.; Lian, B.; Rowley, J.; Xia, N.; Chai, J.; Li, Y.; He, X.-J.; Wierzbicki, A.T.; Qi, Y. A Dicer-Independent Route for Biogenesis of siRNAs that Direct DNA Methylation in Arabidopsis. Mol. Cell 2016, 61, 222-235. [CrossRef]

42. Tester, M.; Langridge, P. Breeding Technologies to Increase Crop Production in a Changing World. Science 2010, 327, 818-822. [CrossRef]

43. Sharma, V.K.; Basu, S.; Chakraborty, S. RNAi mediated broad-spectrum transgenic resistance in Nicotiana benthamiana to chilliinfecting begomoviruses. Plant Cell Rep. 2015, 34, 1389-1399. [CrossRef]

44. Rupp, J.; Cruz, L.F.; Trick, H.; Fellers, J.P. RNAi-Mediated, Stable Resistance to Triticum mosaic virus in Wheat. Crop Sci. 2016, 56, 1602-1610. [CrossRef]

45. Ahmed, M.M.S.; Bian, S.; Wang, M.; Zhao, J.; Zhang, B.; Liu, Q.; Zhang, C.; Tang, S.; Gu, M.; Yu, H. RNAi-mediated resistance to rice black-streaked dwarf virus in transgenic rice. Transgenic Res. 2017, 26, 197-207. [CrossRef]

46. Hameed, A.; Tahir, M.N.; Asad, S.; Bilal, R.; Van Eck, J.; Jander, G.; Mansoor, S. RNAi-Mediated Simultaneous Resistance Against Three RNA Viruses in Potato. Mol. Biotechnol. 2017, 59, 73-83. [CrossRef] [PubMed]

47. Yang, X.; Niu, L.; Zhang, W.; Yang, J.; Xing, G.; He, H.; Guo, D.; Du, Q.; Qian, X.; Yao, Y.; et al. RNAi-mediated SMV P3 cistron silencing confers significantly enhanced resistance to multiple Potyvirus strains and isolates in transgenic soybean. Plant Cell Rep. 2018, 37, 103-114. [CrossRef] [PubMed]

48. Kumari, A.; Hada, A.; Subramanyam, K.; Theboral, J.; Misra, S.; Ganapathi, A.; Malathi, V.G. RNAi-mediated resistance to yellow mosaic viruses in soybean targeting coat protein gene. Acta Physiol. Plant 2018, 40, 1-12. [CrossRef]

49. Senthilraja, C.; Reddy, M.G.; Rajeswaran, J.; Kokiladevi, E.; Velazhahan, R. RNA interference-mediated resistance to Tobacco streak virus in transgenic peanut. Australas. Plant Pathol. 2018, 47, 227-230. [CrossRef]

50. Malathi, P.; Muzammil, S.A.; Krishnaveni, D.; Balachandran, S.; Mangrauthia, S.K. Coat protein 3 of Rice tungro spherical virus is the key target gene for development of RNAi mediated tungro disease resistance in rice. Agri Gene 2019, 12, 100084. [CrossRef]

51. Gao, L.; Luo, J.; Ding, X.; Wang, T.; Hu, T.; Song, P.; Zhai, R.; Zhang, H.; Zhang, K.; Li, K.; et al. Soybean RNA interference lines silenced for eIF4E show broad potyvirus resistance. Mol. Plant Pathol. 2019, 21, 303-317. [CrossRef]

52. Tzean, Y.; Chang, H.-H.; Tu, T.-C.; Hou, B.H.; Chen, H.-M.; Chiu, Y.-S.; Chou, W.-Y.; Chang, L.; Yeh, H.-H. Engineering Plant Resistance to Tomato Yellow Leaf Curl Thailand Virus Using a Phloem-Specific Promoter Expressing Hairpin RNA. Mol. Plant-Microbe Interact. 2020, 33, 87-97. [CrossRef]

53. Escobar, M.A.; Civerolo, E.L.; Summerfelt, K.R.; Dandekar, A.M. RNAi-mediated oncogene silencing confers resistance to crown gall tumorigenesis. Proc. Natl. Acad. Sci. USA 2001, 98, 13437-13442. [CrossRef]

54. Katiyar-Agarwal, S.; Morgan, R.; Dahlbeck, D.; Borsani, O.; Villegas, A.; Zhu, J.-K.; Staskawicz, B.J.; Jin, H. A pathogen-inducible endogenous siRNA in plant immunity. Proc. Natl. Acad. Sci. USA 2006, 103, 18002-18007. [CrossRef]

55. Enrique, R.; Siciliano, F.; Favaro, M.A.; Gerhardt, N.; Roeschlin, R.; Rigano, L.; Castagnaro, A.; Vojnov, A.; Sendin, L.; Marano, M.R. Novel demonstration of RNAi in citrus reveals importance of citrus callose synthase in defence against Xanthomonas citri subsp. citri. Plant Biotechnol. J. 2011, 9, 394-407. [CrossRef] [PubMed]

56. Sanju, S.; Siddappa, S.; Thakur, A.; Shukla, P.K.; Srivastava, N.; Pattanayak, D.; Sharma, S.K.; Singh, B.P. Host-mediated gene silencing of a single effector gene from the potato pathogen Phytophthora infestans imparts partial resistance to late blight disease. Funct. Integr. Genom. 2015, 15, 697-706. [CrossRef] [PubMed]

57. Cheng, W.; Song, X.-S.; Xiao-Li, Q.; Cao, L.-H.; Sun, K.; Qiu, X.-L.; Xu, Y.-B.; Yang, P.; Huang, T.; Zhang, J.-B.; et al. Host-induced gene silencing of an essential chitin synthase gene confers durable resistance to Fusarium head blight and seedling blight in wheat. Plant Biotechnol. J. 2015, 13, 1335-1345. [CrossRef] [PubMed]

58. Ghag, S.B.; Shekhawat, U.K.S.; Ganapathi, T.R. Host-induced post-transcriptional hairpin RNA-mediated gene silencing of vital fungal genes confers efficient resistance against Fusarium wilt in banana. Plant Biotechnol. J. 2014, 12, 541-553. [CrossRef]

59. Andrade, C.M.; Tinoco, M.L.P.; Rieth, A.F.; Maia, F.C.O.; Aragão, F.J.L. Host-induced gene silencing in the necrotrophic fungal pathogen Sclerotinia sclerotiorum. Plant Pathol. 2016, 65, 626-632. [CrossRef]

60. Bharti, P.; Jyoti, P.; Kapoor, P.; Sharma, V.; Shanmugam, V.; Yadav, S.K. Host-induced silencing of pathogenicity genes enhances resistance to Fusarium oxysporum wilt in tomato. Mol. Biotechnol. 2017, 59, 343-352. [CrossRef]

61. Zhu, L.; Zhu, J.; Liu, Z.; Wang, Z.; Zhou, C.; Wang, H. Host-induced gene silencing of rice blast fungus Magnaporthe oryzae pathogenicity genes mediated by the brome mosaic virus. Genes 2017, 8, 241. [CrossRef]

62. Tiwari, I.M.; Jesuraj, A.; Kamboj, R.; Devanna, B.N.; Botella, J.; Sharma, T.R. Host Delivered RNAi, an efficient approach to increase rice resistance to sheath blight pathogen (Rhizoctonia solani). Sci. Rep. 2017, 7, 1-14. [CrossRef]

63. Majumdar, R.; Rajasekaran, K.; Sickler, C.; Lebar, M.; Musungu, B.M.; Fakhoury, A.M.; Payne, G.A.; Geisler, M.; Carter-Wientjes, C.; Wei, Q.; et al. The pathogenesis-related maize seed (PRms ) gene plays a role in resistance to Aspergillus flavus infection and aflatoxin contamination. Front. Plant Sci. 2017, 8, 1-11. [CrossRef]

64. Pareek, M.; Rajam, M.V. RNAi-mediated silencing of MAP kinase signalling genes (Fmk1, Hog1, and Pbs2) in Fusarium oxysporum reduces pathogenesis on tomato plants. Fungal Biol. 2017, 121, 775-784. [CrossRef] [PubMed] 
65. Gilbert, M.K.; Majumdar, R.; Rajasekaran, K.; Chen, Z.-Y.; Wei, Q.; Sickler, C.M.; Lebar, M.D.; Cary, J.W.; Frame, B.R.; Wang, K. RNA interference based silencing of the alpha-amylase (amy1) gene in Aspergillus flavus decreases fungal growth and aflatoxin production in maize kernels. Planta 2018, 247, 1465-1473. [CrossRef] [PubMed]

66. Yoshioka, M.; Adachi, A.; Sato, Y.; Doke, N.; Kondo, T.; Yoshioka, H. RNAi of the sesquiterpene cyclase gene for phytoalexin production impairs pre- and post-invasive resistance to potato blight pathogens. Mol. Plant Pathol. 2019, 20, 907-922. [CrossRef]

67. Wang, L.; Wang, H.; He, S.; Meng, F.; Zhang, C.; Fan, S.; Wu, J.; Zhang, S.; Xu, P. GmSnRK1. 1, a sucrose nonfermenting-1 (SNF1)-Related Protein Kinase, Promotes Soybean Resistance to Phytophthora sojae. Front. Plant Sci. 2019, 10, 996. [CrossRef] [PubMed]

68. Singh, N.; Mukherjee, S.K.; Rajam, M.V. Silencing of the ornithine decarboxylase gene of Fusarium oxysporum f. sp. lycopersici by host-induced RNAi confers resistance to Fusarium wilt in tomato. Plant Mol. Biol. Rep. 2020, 38, 419-429. [CrossRef]

69. Mamta; Reddy, K.R.K.; Rajam, M.V. Targeting chitinase gene of Helicoverpa armigera by host-induced RNA interference confers insect resistance in tobacco and tomato. Plant Mol. Biol. 2016, 90, 281-292. [CrossRef]

70. Malik, H.J.; Raza, A.; Amin, I.; Scheffler, J.A.; Scheffler, B.E.; Brown, J.K.; Mansoor, S. RNAi-mediated mortality of the whitefly through transgenic expression of double- stranded RNA homologous to acetylcholinesterase and ecdysone receptor in tobacco plants. Sci. Rep. 2016, 6, 1-11. [CrossRef] [PubMed]

71. Ibrahim, A.B.; Monteiro, T.R.; Cabral, G.; Aragão, F.J.L. RNAi-mediated resistance to whitefly (Bemisia tabaci) in genetically engineered lettuce (Lactuca sativa). Transgenic Res. 2017, 26, 613-624. [CrossRef] [PubMed]

72. Bhatia, V.; Bhattacharya, R. Host-mediated RNA interference targeting a cuticular protein gene impaired fecundity in the green peach aphid Myzus persicae. Pest Manag. Sci. 2018, 74, 2059-2068. [CrossRef]

73. Shin, Y.H.; Lee, S.H.; Park, Y.-D. Development of mite (Tetranychus urticae)-resistant transgenic Chinese cabbage using plantmediated RNA interference. Hortic. Environ. Biotechnol. 2020, 61, 305-315. [CrossRef]

74. Dutta, T.K.; Papolu, P.K.; Banakar, P.; Choudhary, D.; Sirohi, A.; Rao, U. Tomato transgenic plants expressing hairpin construct of a nematode protease gene conferred enhanced resistance to root-knot nematodes. Front. Microbiol. 2015, 6, 260. [CrossRef] [PubMed]

75. Li, Y.; Wang, K.; Lu, Q.; Du, J.; Wang, Z.; Wang, D.; Sun, B.; Li, H. Transgenic Nicotiana benthamiana plants expressing a hairpin RNAi construct of a nematode Rs-cps gene exhibit enhanced resistance to Radopholus similis. Sci. Rep. 2017, 7, 1-11. [CrossRef]

76. Chukwurah, P.N.; Poku, S.A.; Yokoyama, A.; Fukuda, H.; Shishido, M.; Nakamura, I. Expression of Meloidogyne incognita PolA1 hairpin RNA reduced nematode multiplication in transgenic tomato. Plant Biotechnol. Rep. 2019, 13, 591-601. [CrossRef]

77. Hu, Y.; You, J.; Li, C.; Pan, F.; Wang, C. The Heterodera glycines effector Hg16B09 is required for nematode parasitism and suppresses plant defense response. Plant Sci. 2019, 289, 110271. [CrossRef] [PubMed]

78. Tian, B.; Li, J.; Vodkin, L.O.; Todd, T.C.; Finer, J.J.; Trick, H.N. Host-derived gene silencing of parasite fitness genes improves resistance to soybean cyst nematodes in stable transgenic soybean. Theor. Appl. Genet. 2019, 132, 2651-2662. [CrossRef]

79. Joshi, I.; Kumar, A.; Kohli, D.; Singh, A.K.; Sirohi, A.; Subramaniam, K.; Chaudhury, A.; Jain, P.K. Conferring root-knot nematode resistance via host-delivered RNAi-mediated silencing of four Mi-msp genes in Arabidopsis. Plant Sci. 2020, $298,110592$. [CrossRef] [PubMed]

80. Shi, Y.; Liu, P.; Xia, Y.; Wei, P.; Li, W.; Zhang, W.; Chen, X.; Cao, P.; Xu, Y.; Jin, L.; et al. Downregulation of the lycopene e-cyclase gene confers tolerance to salt and drought stress in Nicotiana tabacum. Acta Physiol. Plant 2015, 37, 1-15. [CrossRef]

81. Cui, P.; Liu, H.; Islam, F.; Li, L.; Farooq, M.A.; Ruan, S.; Zhou, W. OsPEX11, a peroxisomal Biogenesis Factor 11, contributes to salt stress tolerance in Oryza sativa. Front. Plant Sci. 2016, 7, 1357. [CrossRef] [PubMed]

82. Kim, J.A.; Jung, H.-E.; Hong, J.K.; Hermand, V.; McClung, C.R.; Lee, Y.-H.; Kim, J.Y.; Lee, S.I.; Jeong, M.-J.; Kim, J.; et al. Reduction of GIGANTEA expression in transgenic Brassica rapa enhances salt tolerance. Plant Cell Rep. 2016, 35, 1943-1954. [CrossRef] [PubMed]

83. Szechyńska-Hebda, M.; Czarnocka, W.; Hebda, M.; Karpiński, S. PAD4, LSD1 and EDS1 regulate drought tolerance, plant biomass production, and cell wall properties. Plant Cell Rep. 2016, 35, 527-539. [CrossRef] [PubMed]

84. Ninghui, C.; Wu, Q.; Peng, Z.; Sprague, S.A.; Wang, W.; Park, J.; Akhunov, E.; Jagadish, K.S.V.; Nakata, P.; Cheng, N.; et al Silencing of OsGRXS17 in rice improves drought stress tolerance by modulating ROS accumulation and stomatal closure. Sci. Rep. 2017, 7, 1-14. [CrossRef]

85. Yin, X.; Huang, L.; Wang, M.; Cui, Y.; Xia, X. OsDSR-1, a calmodulin-like gene, improves drought tolerance through scavenging of reactive oxygen species in rice (Oryza sativa L.). Mol. Breed. 2017, 37, 75. [CrossRef]

86. Jin, Y.; Pan, W.; Zheng, X.; Cheng, X.; Liu, M.; Ma, H.; Ge, X. OsERF101, an ERF family transcription factor, regulates drought stress response in reproductive tissues. Plant Mol. Biol. 2018, 98, 51-65. [CrossRef]

87. Zhu, M.; Meng, X.; Cai, J.; Li, G.; Dong, T.; Li, Z. Basic leucine zipper transcription factor SlbZIP1 mediates salt and drought stress tolerance in tomato. BMC Plant Biol. 2018, 18, 83. [CrossRef] [PubMed]

88. Park, J.-S.; Yu, J.-G.; Lee, G.-H.; Park, Y.-D. Drought tolerance induction in transgenic tobacco through RNA interference of BrDST71, a drought responsive gene from Chinese cabbage. Hortic. Environ. Biotechnol. 2018, 59, 749-757. [CrossRef]

89. Wang, W.; Wang, W.; Wu, Y.; Li, Q.; Zhang, G.; Shi, R.; Yang, J.; Wang, Y.; Wang, W. The involvement of wheat U box E3 ubiquitin ligase TaPUB1 in salt stress tolerance. J. Integr. Plant Biol. 2019, 62, 631-651. [CrossRef] [PubMed]

90. Yu, Z.; Wang, X.; Mu, X.; Zhang, L. RNAi mediated silencing of dehydrin gene WZY2 confers osmotic stress intolerance in transgenic wheat. Funct. Plant Biol. 2019, 46, 877-884. [CrossRef] 
91. Oerke, E.C.; Dehne, H.W.; Schonbeck, F.; Weber, A. Crop Production and Crop Protection: Estimated Losses in Major Food and Cash Crops; Elsevier: Amsterdam, The Netherlands, 2012.

92. Waterhouse, P.M.; Graham, M.W.; Wang, M.-B. Virus resistance and gene silencing in plants can be induced by simultaneous expression of sense and antisense RNA. Proc. Natl. Acad. Sci. USA 1998, 95, 13959-13964. [CrossRef]

93. Missiou, A.; Kalantidis, K.; Boutla, A.; Tzortzakaki, S.; Tabler, M.; Tsagris, M. Generation of transgenic potato plants highly resistant to potato virus Y (PVY) through RNA silencing. Mol. Breed. 2004, 14, 185-197. [CrossRef]

94. Andika, I.B.; Kondo, H.; Tamada, T. Evidence that RNA silencing-mediated resistance to beet necrotic yellow vein virus is less effective in roots than in leaves. Mol. Plant-Microbe Interact. 2005, 18, 194-204. [CrossRef] [PubMed]

95. Hily, J.-M.; Ravelonandro, M.; Damsteegt, V.; Bassett, C.; Petri, C.; Liu, Z.; Scorza, R. Plum pox virus coat protein gene Intronhairpin-RNA (ihpRNA) constructs provide resistance to plum pox virus in Nicotiana benthamiana and Prunus domestica. J. Am. Soc. Hortic. Sci. 2007, 132, 850-858. [CrossRef]

96. Bonfim, K.; Faria, J.C.; Nogueira, E.O.P.L.; Mendes, É.A.; Aragão, F.J.L. RNAi-mediated resistance to Bean golden mosaic virus in genetically engineered common bean (Phaseolus vulgaris). Mol. Plant-Microbe Interact. 2007, 20, 717-726. [CrossRef] [PubMed]

97. Vanitharani, R.; Chellappan, P.; Fauquet, C.M. Short interfering RNA-mediated interference of gene expression and viral DNA accumulation in cultured plant cells. Proc. Natl. Acad. Sci. USA 2003, 100, 9632-9636. [CrossRef]

98. Vanderschuren, H.; Alder, A.; Zhang, P.; Gruissen, W. Dose-dependent RNAi-mediated germinivirus resistance in the tropical root crop cassava. Plant Mol. Biol. 2009, 70, 265-272. [CrossRef]

99. Patil, B.; Ogwok, E.; Wagaba, H.; Mohammed, I.U.; Yadav, J.S.; Bagewadi, B.; Taylor, N.J.; Kreuze, J.; Maruthi, M.N.; Alicai, T.; et al. RNAi mediated resistance to diverse isolates belonging to two virus species involved in Cassava brown streak disease. Mol. Plant Pathol. 2010, 12, 31-41. [CrossRef]

100. Pradeep, K.; Satya, V.K.; Selvapriya, M.; Vijayasamundeeswari, A.; Ladhalakshmi, D.; Paranidharan, V.; Rabindran, R.; Samiyappan, R.; Balasubramanian, P.; Velazhahan, R. Engineering resistance against tobacco streak virus (TSV) in sunflower and tobacco using RNA interference. Biol. Plant 2012, 56, 735-741. [CrossRef]

101. Zhou, Y.; Yuan, Y.; Yuan, F.; Wang, M.; Zhong, H.; Gu, M.; Liang, G. RNAi-directed down-regulation of RSV results in increased resistance in rice (Oryza sativa L.). Biotechnol. Lett. 2012, 34, 965-972. [CrossRef]

102. Kim, H.J.; Kim, M.-J.; Pak, J.H.; Im, H.H.; Lee, D.H.; Kim, K.-H.; Lee, J.-H.; Kim, D.-H.; Choi, H.K.; Jung, H.W.; et al. RNAimediated Soybean mosaic virus (SMV) resistance of a Korean Soybean cultivar. Plant Biotechnol. Rep. 2016, 10, 257-267. [CrossRef]

103. Pooggin, M.M.; Shivaprasad, P.V.; Veluthambi, K.; Hohn, T. RNAi targeting of DNA virus in plants. Nat. Biotechnol. 2003, 21, 131-132. [CrossRef]

104. Worrall, E.; Bravo-Cazar, A.; Nilon, A.T.; Fletcher, S.J.; Robinson, K.E.; Carr, J.; Mitter, N. Exogenous application of RNAi-inducing double-stranded RNA inhibits aphid-mediated transmission of a plant virus. Front. Plant Sci. 2019, 10, 265. [CrossRef]

105. Hamada, W.; Spanu, P.D. Co-suppression of the hydrophobin gene HCf-1 is correlated with antisense RNA biosynthesis in Cladosporium fulvum. Mol. Genet. Genom. 1998, 259, 630-638. [CrossRef] [PubMed]

106. Fitzgerald, A.; van Kan, J.; Plummer, K.M. Simultaneous silencing of multiple genes in the apple scab fungus, Venturia inaequalis, by expression of RNA with chimeric inverted repeats. Fungal Genet. Biol. 2004, 41, 963-971. [CrossRef] [PubMed]

107. Goldoni, M.; Azzalin, G.; Macino, G.; Cogoni, C. Efficient gene silencing by expression of double stranded RNA in Neurospora crassa. Fungal Genet. Biol. 2004, 41, 1016-1024. [CrossRef]

108. Kadotani, N.; Nakayashiki, H.; Tosa, Y.; Mayama, S. RNA silencing in the phytopathogenic fungus Magnaporthe oryzae. Mol. Plant-Microbe Interact. 2003, 16, 769-776. [CrossRef] [PubMed]

109. Hernández, I.; Chacón, O.; Rodriguez, R.; Portieles, R.; López, Y.; Pujol, M.; Borrás-Hidalgo, O. Black shank resistant tobacco by silencing of glutathione S-transferase. Biochem. Biophys. Res. Commun. 2009, 387, 300-304. [CrossRef] [PubMed]

110. Chen, Y.; Gao, Q.; Huang, M.; Liu, Y.; Liu, Z.; Liu, X.; Ma, Z. Characterization of RNA silencing components in the plant pathogenic fungus Fusarium graminearum. Sci. Rep. 2015, 5, srep12500. [CrossRef]

111. Yogindran, S.; Rajam, M.V. RNAi for Crop Improvement. In Plant Biology and Biotechnology; Bahadur, B., Rajam, M.V., Sahijram, L., Krishnamurthy, K., Eds.; Springer: New Delhi, India, 2015; pp. 623-637. [CrossRef]

112. Gheysen, G.; Vanholme, B. RNAi from plants to nematodes. Trends Biotechnol. 2007, 25, 89-92. [CrossRef] [PubMed]

113. Huang, G.; Allen, R.; Davis, E.L.; Baum, T.J.; Hussey, R.S. Engineering broad root-knot resistance in transgenic plants by RNAi silencing of a conserved and essential root-knot nematode parasitism gene. Proc. Natl. Acad. Sci. USA 2006, 103, 14302-14306. [CrossRef] [PubMed]

114. Sindhu, A.S.; Maier, T.R.; Mitchum, M.G.; Hussey, R.S.; Davis, E.L.; Baum, T.J. Effective and specific in planta RNAi in cyst nematodes: Expression interference of four parasitism genes reduces parasitic success. J. Exp. Bot. 2008, 60, 315-324. [CrossRef] [PubMed]

115. Kumar, A.; Kakrana, A.; Sirohi, A.; Subramaniam, K.; Srinivasan, R.; Abdin, M.Z.; Jain, P.K. Host-delivered RNAi-mediated root-knot nematode resistance in Arabidopsis by targeting splicing factor and integrase genes. J. Gen. Plant Pathol. 2017, 83, 91-97. [CrossRef]

116. Tsygankova, V.A.; Andrusevich, Y.V.; Shysha, E.N.; Biliavska, L.O.; Galagan, T.O.; Galkin, A.P.; Yemets, A.; Iutynska, G.A.; Blume, Y.B. RNAi-mediated resistance against plant parasitic nematodes of wheat plants obtained in vitro using bioregulators of microbiological origin. Curr. Chem. Biol. 2019, 13, 73-89. [CrossRef] 
117. Mao, Y.-B.; Cai, W.-J.; Wang, J.-W.; Hong, G.-J.; Tao, X.; Wang, L.-J.; Huang, Y.-P.; Chen, X. Silencing a cotton bollworm P450 monooxygenase gene by plant-mediated RNAi impairs larval tolerance of gossypol. Nat. Biotechnol. 2007, 25, 1307-1313. [CrossRef]

118. A Baum, J.; Bogaert, T.; Clinton, W.; Heck, G.R.; Feldmann, P.; Ilagan, O.; Johnson, S.; Plaetinck, G.; Munyikwa, T.; Pleau, M.; et al. Control of coleopteran insect pests through RNA interference. Nat. Biotechnol. 2007, 25, 1322-1326. [CrossRef]

119. Thakur, N.; Upadhyay, S.K.; Verma, P.C.; Chandrashekar, K.; Tuli, R.; Singh, P.K. Enhanced whitefly resistance in transgenic tobacco plants expressing double stranded RNA of v-ATPase A gene. PLoS ONE 2014, 9, e87235. [CrossRef]

120. Wang, Z.; Dong, Y.; Desneux, N.; Niu, C. RNAi silencing of the HaHMG-CoA reductase gene inhibits oviposition in the Helicoverpa armigera cotton bollworm. PLoS ONE 2013, 8, e67732. [CrossRef] [PubMed]

121. Pardo, J.M. Biotechnology of water and salinity stress tolerance. Curr. Opin. Biotechnol. 2010, 21, 185-196. [CrossRef] [PubMed]

122. Li, D.-H.; Liu, H.; Yang, Y.-L.; Zhen, P.-P.; Liang, J.-S. Down-regulated expression of RACK1 gene by RNA interference enhances drought tolerance in rice. Rice Sci. 2009, 16, 14-20. [CrossRef]

123. Manavalan, L.P.; Chen, X.; Clarke, J.; Salmeron, J.; Nguyen, H.T. RNAi-mediated disruption of squalene synthase improves drought tolerance and yield in rice. J. Exp. Bot. 2012, 63, 163-175. [CrossRef] [PubMed]

124. Wang, L.; Liu, H.; Liwen, W.; Chen, H. Identification and characterization of maize microRNAs involved in the very early stage of seed germination. BMC Genom. 2011, 12, 154. [CrossRef] [PubMed]

125. Wang, T.; Chen, L.; Zhao, M.; Tian, Q.; Zhang, W.-H. Identification of drought-responsive microRNAs in Medicago truncatula by genome-wide high-throughput sequencing. BMC Genom. 2011, 12, 367. [CrossRef]

126. Jan, A.; Maruyama, K.; Todaka, D.; Kidokoro, S.; Abo, M.; Yoshimura, E.; Shinozaki, K.; Nakashima, K.; Yamaguchi-Shinozaki, K. OsTZF1, a CCCH-tandem zinc finger protein, confers delayed senescence and stress tolerance in rice by regulating stress-related genes. Plant Physiol. 2013, 161, 1202-1216. [CrossRef]

127. Yu, W.; Wang, L.; Zhao, R.; Sheng, J.; Zhang, S.; Li, R.; Shen, L. Knockout of SIMAPK3 enhances tolerance to heat stress involving ROS homeostasis in tomato plants. BMC Plant Biol. 2019, 19, 354. [CrossRef] [PubMed]

128. Alam, I.; Salimullah, M. Genetic engineering of eggplant (Solanum melongena L.): Progress, controversy and potential. Hoticulture 2021, 7, 78. [CrossRef]

129. Pandolfini, T. Seedless fruit production by hormonal regulation of fruit set. Nutrients 2009, 1, 168-177. [CrossRef] [PubMed]

130. Varoquaux, F.; Blanvillain, R.; Delseny, M.; Gallois, P. Less is better: New approaches for seedless fruit production. Trends Biotechnol. 2000, 18, 233-242. [CrossRef]

131. Denna, D.W. Effects of genetic parthenocarpy and gynoecious flowering habit on fruit production and growth of cucumber Cucumis sativus L. J. Am. Soc. Hortic. Sci. 1973, 98, 602-604.

132. Tiedjens, V.A. Sex ratios in cucumber flowers as affected by different conditions of soil and light. J. Agric. Res. 1928, 36, 721-746.

133. Falavigna, A.; Soressi, G.P. Influence of the pat-sha gene on plant and fruit traits in tomato (L. esculentum Mill.). In Proceedings of the 10th Meeting of the EUCARPIA Tomato Working Group, Salerno, Italy, 2-6 September 1987; p. 128.

134. De Jong, M.; Wolters-Arts, M.; Feron, R.; Mariani, C.; Vriezen, W.H. The Solanum lycopersicum auxin response factor 7 (SlARF7) regulates auxin signaling during tomato fruit set and development. Plant J. 2009, 57, 160-170. [CrossRef]

135. Schijlen, E.G.; de Vos, C.R.; Martens, S.; Jonker, H.H.; Rosin, F.M.; Molthoff, J.W.; Tikunov, Y.M.; Angenent, G.C.; van Tunen, A.J.; Bovy, A.G. RNA interference silencing of chalcone synthase, the first step in the flavonoid biosynthesis pathway, leads to parthenocarpic tomato fruits. Plant Physiol. 2007, 144, 1520-1530. [CrossRef]

136. Mahajan, M.; Ahuja, P.S.; Yadav, S.K. Post-transcriptional silencing of flavonol synthase mRNA in tobacco leads to fruits with arrested seed set. PLoS ONE 2011, 6, e28315. [CrossRef] [PubMed]

137. Molesini, B.; Pandolfini, T.; Rotino, G.L.; Dani, V.; Spena, A. Aucsia gene silencing causes parthenocarpic fruit development in tomato. Plant Physiol. 2009, 149, 534-548. [CrossRef] [PubMed]

138. Takei, H.; Shinozaki, Y.; Yano, R.; Kashojiya, S.; Hernould, M.; Chevalier, C.; Ezura, H.; Ariizumi, T. Loss-of-function of a tomato receptor-like kinase impairs male fertility and induces parthenocarpic fruit set. Front. Plant Sci. 2019, 10, 403. [CrossRef]

139. Xiong, A.-S.; Yao, Q.-H.; Peng, R.-H.; Li, X.; Han, P.-L.; Fan, H.-Q. Different effects on ACC oxidase gene silencing triggered by RNA interference in transgenic tomato. Plant Cell Rep. 2005, 23, 639-646. [CrossRef]

140. Gupta, A.; Pal, R.K.; Rajam, M.V. Delayed ripening and improved fruit processing quality in tomato by RNAi-mediated silencing of three homologs of 1-aminopropane-1-carboxylate synthase gene. J. Plant Physiol. 2013, 170, 987-995. [CrossRef]

141. Meli, V.S.; Ghosh, S.; Prabha, T.N.; Chakraborty, N.; Chakraborty, S.; Datta, A. Enhancement of fruit shelf life by suppressing N-glycan processing enzymes. Proc. Natl. Acad. Sci. USA 2010, 107, 2413-2418. [CrossRef]

142. Luo, Z.; Zhang, J.; Li, J.; Yang, C.; Wang, T.; Ouyang, B.; Li, H.; Giovannoni, J.; Ye, Z. A STAY GREEN protein SISGR1 regulates lycopene and $\beta$-carotene accumulation by interacting directly with SIPSY1 during ripening processes in tomato. New Phytol. 2013, 198, 442-452. [CrossRef]

143. Elitzur, T.; Yakir, E.; Quansah, L.; Zhangjun, F.; Vrebalov, J.; Khayat, E.; Giovannoni, J.J.; Friedman, H. Banana MaMADS transcription factors are necessary for fruit ripening and molecular tools to promote shelf-life and food security. Plant Physiol. 2016, 171, 380-391. [CrossRef]

144. Yang, L.; Huang, W.; Xiong, F.; Xian, Z.; Su, D.; Ren, M.; Li, Z. Silencing of Sl PL, which encodes a pectate lyase in tomato, confers enhanced fruit firmness, prolonged shelf-life and reduced susceptibility to grey mould. Plant Biotechnol. J. 2017, 15, 1544-1555. [CrossRef] [PubMed] 
145. Davuluri, G.R.; Van Tuinen, A.; Fraser, P.D.; Manfredonia, A.; Newman, R.; Burgess, D.; Brummell, D.; King, S.R.; Palys, J.; Uhlig, J.; et al. Fruit-specific RNAi-mediated suppression of DET1 enhances carotenoid and flavonoid content in tomatoes. Nat. Biotechnol. 2005, 23, 890-895. [CrossRef] [PubMed]

146. Chen, S.; Hajirezaei, M.R.; Zanor, M.; Hornyik, C.; Debast, S.; Lacomme, C.; Fernie, A.R.; Sonnewald, U.; Börnke, F. RNA interference-mediated repression of sucrose phosphatase in transgenic potato tubers (Solanum tuberosum) strongly affects the hexose to sucrose ratio upon cold storage with only minor effects on total soluble carbohydrate accumulation. Plant Cell Environ. 2007, 31, 165-176. [CrossRef]

147. Nawaz-Ul-Rehman, M.S.; Mansoor, S.; Khan, A.A.; Zafar, Y.; Briddon, R.W. RNAi-mediated male sterility of tobacco by silencing TA29. Mol. Biotechnol. 2007, 36, 159-165. [CrossRef]

148. Tehseen, M.; Imran, M.; Hussain, M.; Irum, S.; Ali, S.; Mansoor, S.; Zafar, Y. Development of male sterility by silencing Bcp1 gene of Arabidopsis through RNA interference. Afr. J. Biotechnol. 2010, 9, 2736-2741. Available online: http:/ / www.academicjournals. org / AJB (accessed on 27 August 2021).

149. Sinha, R.; Rajam, M.V. RNAi silencing of three homologues of S-adenosylmethionine decarboxylase gene in tapetal tissue of tomato results in male sterility. Plant Mol. Biol. 2013, 82, 169-180. [CrossRef]

150. Sandhu, A.P.S.; Abdelnoor, R.V.; Mackenzie, S.A. Transgenic induction of mitochondrial rearrangements for cytoplasmic male sterility in crop plants. Proc. Natl. Acad. Sci. USA 2007, 104, 1766-1770. [CrossRef] [PubMed]

151. Nishihara, M.; Nakatsuka, T.; Yamamura, S. Flavonoid components and flower color change in transgenic tobacco plants by suppression of chalcone isomerase gene. FEBS Lett. 2005, 579, 6074-6078. [CrossRef] [PubMed]

152. Kamiishi, Y.; Otani, M.; Takagi, H.; Han, D.-S.; Mori, S.; Tatsuzawa, F.; Okuhara, H.; Kobayashi, H.; Nakano, M. Flower color alteration in the liliaceous ornamental Tricyrtis sp. by RNA interference-mediated suppression of the chalcone synthase gene. Mol. Breed. 2012, 30, 671-680. [CrossRef]

153. Nakatsuka, T.; Mishiba, K.-I.; Abe, Y.; Kubota, A.; Kakizaki, Y.; Yamamura, S.; Nishihara, M. Flower color modification of gentian plants by RNAi-mediated gene silencing. Plant Biotechnol. 2008, 25, 61-68. [CrossRef]

154. Nakatsuka, T.; Mishiba, K.-I.; Kubota, A.; Abe, Y.; Yamamura, S.; Nakamura, N.; Tanaka, Y.; Nishihara, M. Genetic engineering of novel flower colour by suppression of anthocyanin odification genes in gentian. J. Plant Physiol. 2010, 167, 231-237. [CrossRef]

155. He, H.; Ke, H.; Keting, H.; Qiaoyan, X.; Silan, D. Flower colour modification of chrysanthemum by suppression of F3'H and overexpression of the exogenous Senecio cruentus F3'5' H gene. PLoS ONE 2013, 8, e74395. [CrossRef]

156. White, P.J.; Broadley, M. Biofortification of crops with seven mineral elements often lacking in human diets-iron, zinc, copper, calcium, magnesium, selenium and iodine. New Phytol. 2009, 182, 49-84. [CrossRef]

157. Flores, T.; Karpova, O.; Su, X.; Zeng, P.; Bilyeu, K.; Sleper, D.A.; Nguyen, H.T.; Zhang, Z.J. Silencing of GmFAD3 gene by siRNA leads to low $\alpha$-linolenic acids (18:3) of fad3-mutant phenotype in soybean [Glycine max (Merr.)]. Transgenic Res. 2008, 17, 839-850. [CrossRef]

158. Ozseyhan, M.E.; Li, P.; Na, G.; Li, Z.; Wang, C.; Lu, C. Improved fatty acid profiles in seeds of Camelina sativa by artificial microRNA mediated FATB gene suppression. Biochem. Biophys. Res. Commun. 2018, 503, 621-624. [CrossRef] [PubMed]

159. Kusaba, M.; Miyahara, K.; Iida, S.; Fukuoka, H.; Takano, T.; Sassa, H.; Nishimura, M.; Nishio, T. Low glutelin content1: A dominant mutation that suppresses the glutelin multigene family via RNA silencing in rice. Plant Cell 2003, 15, 1455-1467. [CrossRef]

160. Regina, A.; Bird, A.; Topping, D.; Bowden, S.; Freeman, J.; Barsby, T.; Kosar-Hashemi, B.; Li, Z.; Rahman, S.; Morell, M. Highamylose wheat generated by RNA interference improves indices of large-bowel health in rats. Proc. Natl. Acad. Sci. USA 2006, 103, 3546-3551. [CrossRef]

161. Weise, S.E.; Aung, K.; Jarou, Z.J.; Mehrshahi, P.; Li, Z.; Hardy, A.C.; Carr, D.J.; Sharkey, T.D. Engineering starch accumulation by manipulation of phosphate metabolism of starch. Plant Biotechnol. J. 2012, 10, 545-554. [CrossRef]

162. Yu, B.; Lydiate, D.J.; Young, L.W.; Schäfer, U.A.; Hannoufa, A. Enhancing the carotenoid content of Brassica napus seeds by downregulating lycopene epsilon cyclase. Transgenic Res. 2008, 17, 573-585. [CrossRef]

163. Aggarwal, S.; Kumar, A.; Bhati, K.K.; Kaur, G.; Shukla, V.; Tiwari, S.; Pandey, A.K. RNAi-mediated downregulation of inositol pentakisphosphate kinase (IPK1) in wheat grains decreases phytic acid levels and increases Fe and Zn accumulation. Front. Plant Sci. 2018, 9, 259. [CrossRef]

164. Borgio, J.F. RNA interference (RNAi) technology: A promising tool for medicinal plant research. J. Med. Plant Res. 2009, 3, 1176-1183. Available online: http:/ / www.academicjournals.org/JMPR (accessed on 27 August 2021).

165. Allen, R.S.; Millgate, A.G.; A Chitty, J.; Thisleton, J.; Miller, J.A.C.; Fist, A.J.; Gerlach, W.L.; Larkin, P.J. RNAi-mediated replacement of morphine with the nonnarcotic alkaloid reticuline in opium poppy. Nat. Biotechnol. 2004, 22, 1559-1566. [CrossRef]

166. Ogita, S.; Uefuji, H.; Yamaguchi, Y.; Koizumi, N.; Sano, H. Producing decaffeinated coffee plants. Nature 2003, 423, 823. [CrossRef]

167. Mohanpuria, P.; Kumar, V.; Ahuja, P.S.; Yadav, S.K. Producing low-caffeine tea through post-transcriptional silencing of caffeine synthase mRNA. Plant Mol. Biol. 2011, 76, 523-534. [CrossRef] [PubMed]

168. Zhang, S.; Li, H.; Liang, X.; Yan, Y.; Xia, P.; Jia, Y.; Liang, Z. Enhanced production of phenolic acids in Salvia miltiorrhiza hairy root cultures by combing the RNAi-mediated silencing of chalcone synthase gene with salicylic acid treatment. Biochem. Eng. J. 2015, 103, 185-192. [CrossRef] 
169. Wang, Q.; Reddy, V.; Panicker, D.; Mao, H.-Z.; Kumar, N.; Rajan, C.; Venkatesh, P.N.; Chua, N.-H.; Sarojam, R. Metabolic engineering of terpene biosynthesis in plants using a trichome specific transcription factor Ms YABBY 5 from spearmint (Mentha spicata). Plant Biotechnol. J. 2016, 14, 1619-1632. [CrossRef]

170. Jamaluddin, N.D.; Rohani, E.R.; Noor, N.M.; Goh, H.-H. Transcriptome-wide effect of DE-ETIOLATED1 (DET1) suppression in embryogenic callus of Carica papaya. J. Plant Res. 2019, 132, 181-195. [CrossRef] [PubMed]

171. Zhang, P.; Du, H.; Wang, J.; Pu, Y.; Yang, C.; Yan, R.; Yang, H.; Cheng, H.; Yu, D. Multiplex CRISPR/Cas9 mediated metabolic engineering increases soya bean isoflavone content and resistance to soya bean mosaic virus. Plant Biotechnol. J. 2019, 18, 1384-1395. [CrossRef] [PubMed]

172. Christian, M.; Cermak, T.; Doyle, E.L.; Schmidt, C.; Zhang, F.; Hummel, A.; Bogdanove, A.J.; Voytas, D.F. Targeting DNA double-strand breaks with TAL effector nucleases. Genetics 2010, 186, 757-761. [CrossRef]

173. Kim, Y.G.; Cha, J.; Chandrasegaran, S. Hybrid restriction enzymes: Zinc finger fusions to Fok I cleavage domain. Proc. Natl. Acad. Sci. USA 1996, 93, 1156-1160. [CrossRef] [PubMed]

174. Puchta, H.; Fauser, F. Synthetic nucleases for genome engineering in plants: Prospects for a bright future. Plant J. 2013, 78, 727-741. [CrossRef]

175. Li, Q.; Sapkota, M.; Van Der Knaap, E. Perspectives of CRISPR/Cas-mediated cis-engineering in horticulture: Unlocking the neglected potential for crop improvement. Hortic. Res. 2020, 7, 1-11. [CrossRef]

176. Ishino, Y.; Shinagawa, H.; Makino, K.; Amemura, M.; Nakata, A. Nucleotide sequence of the iap gene, responsible for alkaline phosphatase isozyme conversion in Escherichia coli, and identification of the gene product. J. Bacteriol. 1987, 169, 5429-5433. [CrossRef]

177. Jansen, R.; Van Embden, J.D.A.; Gaastra, W.; Schouls, L.M. Identification of genes that are associated with DNA repeats in prokaryotes. Mol. Microbiol. 2002, 43, 1565-1575. [CrossRef] [PubMed]

178. Bolotin, A.; Quinquis, B.; Sorokin, A.; Ehrlich, S.D. Clustered regularly interspaced short palindrome repeats (CRISPRs) have spacers of extrachromosomal origin. Microbiology 2005, 151, 2551-2561. [CrossRef] [PubMed]

179. Mojica, F.J.; Diez-Villasenor, C.; Garcia-Martinez, J.; Soria, E. Intervening sequences of regularly spaced prokaryotic repeats derive from foreign genetic elements. J. Mol. Evol. 2005, 60, 174-182. [CrossRef]

180. Pourcel, C.; Salvignol, G.; Vergnaud, G. CRISPR elements in Yersinia pestis acquire new repeats by preferential uptake of bacteriophage DNA, and provide additional tools for evolutionary studies. Microbiology 2005, 151, 653-663. [CrossRef]

181. Barrangou, R.; Fremaux, C.; Deveau, H.; Richards, M.; Boyaval, P.; Moineau, S.; Romero, D.A.; Horvath, P. CRISPR provides acquired resistance against viruses in prokaryotes. Science 2007, 315, 1709-1712. [CrossRef]

182. Kunin, V.; Sorek, R.; Hugenholtz, P. Evolutionary conservation of sequence and secondary structures in CRISPR repeats. Genome Biol. 2007, 8, R61-R67. [CrossRef]

183. Mojica, F.J.; Díez-Villaseñor, C.; García-Martínez, J.; Almendros, C. Short motif sequences determine the targets of the prokaryotic CRISPR defence system. Microbiology 2009, 155, 733-740. [CrossRef]

184. Brouns, S.J.J.; Jore, M.M.; Lundgren, M.; Westra, E.R.; Slijkhuis, R.J.H.; Snijders, A.P.L.; Dickman, M.J.; Makarova, K.S.; Koonin, E.V.; Van Der Oost, J. Small CRISPR RNAs guide antiviral defense in prokaryotes. Science 2008, 321, 960-964. [CrossRef] [PubMed]

185. Garneau, J.E.; Dupuis, M.-È; Villion, M.; Romero, D.A.; Barrangou, R.; Boyaval, P.; Fremaux, C.; Horvath, P.; Magadán, A.H.; Moineau, S. The CRISPR/Cas bacterial immune system cleaves bacteriophage and plasmid DNA. Nature 2010, 468, 67-71. [CrossRef]

186. Makarova, K.S.; Haft, D.H.; Barrangou, R.; Brouns, S.J.J.; Charpentier, E.; Horvath, P.; Moineau, S.; Mojica, F.J.M.; Wolf, Y.I.; Yakunin, A.F.; et al. Evolution and classification of the CRISPR-Cas systems. Nat. Rev. Microbiol. Genet. 2011, 9, 467-477. [CrossRef]

187. Li, C.; Brant, E.; Budak, H.; Zhang, B. CRISPR/Cas: A Nobel Prize award-winning precise genome editing technology for gene therapy and crop improvement. J. Zhejiang Univ. Sci. B 2021, 22, 253-284. [CrossRef] [PubMed]

188. Sinkunas, T.; Gasiunas, G.; Fremaux, C.; Barrangou, R.; Horvath, P.; Siksnys, V. Cas3 is a single-stranded DNA nuclease and ATP-dependent helicase in the CRISPR/Cas immune system. EMBO J. 2011, 30, 1335-1342. [CrossRef] [PubMed]

189. Deltcheva, E.; Chylinski, K.; Sharma, C.M.; Gonzales, K.; Chao, Y.; Pirzada, Z.A.; Eckert, M.R.; Vogel, J.; Charpentier, E. CRISPR RNA maturation by trans-encoded small RNA and host factor RNase III. Nature 2011, 471, 602-607. [CrossRef]

190. Wei, Y.; Terns, R.M.; Terns, M.P. Cas9 function and host genome sampling in Type II-A CRISPR-Cas adaptation. Genes Dev. 2015, 29, 356-361. Available online: http:/ / www.genesdev.org/cgi/doi/10.1101/gad.257550.114 (accessed on 27 August 2021). [CrossRef]

191. Chylinski, K.; Le Rhun, A.; Charpentier, E. The tracrRNA and Cas9 families of type II CRISPR-Cas immunity systems. RNA Biol. 2013, 10, 726-737. [CrossRef] [PubMed]

192. Koonin, E.V.; Makarova, K.S. CRISPR-Cas: Evolution of an RNA-based adaptive immunity system in prokaryotes. RNA Biol. 2013, 10, 679-686. [CrossRef] [PubMed]

193. Rath, D.; Amlinger, L.; Rath, A.; Lundgren, M. The CRISPR-Cas immune system: Biology, mechanisms and applications. Biochimie 2015, 117, 119-128. [CrossRef]

194. Marraffini, L.A.; Sontheimer, E.J. CRISPR interference limits horizontal gene transfer in Staphylococci by targeting DNA. Science 2008, 322, 1843-1845. [CrossRef] [PubMed] 
195. Marraffini, L.A.; Sontheimer, E.J. Self versus non-self discrimination during CRISPR RNA-directed immunity. Nat. Cell Biol. 2010, 463, 568-571. [CrossRef]

196. Hale, C.R.; Zhao, P.; Olson, S.; Duff, M.O.; Graveley, B.R.; Wells, L.; Terns, R.M.; Terns, M.P. RNA-guided RNA cleavage by a CRISPR RNA-Cas protein complex. Cell 2009, 139, 945-956. [CrossRef]

197. Cong, L.; Ran, F.A.; Cox, D.; Lin, S.; Barretto, R.; Habib, N.; Hsu, P.D.; Wu, X.; Jiang, W.; Marraffini, L.A.; et al. Multiplex genome engineering using CRISPR/Cas systems. Science 2013, 339, 819-823. [CrossRef] [PubMed]

198. Mali, P.; Yang, L.; Esvelt, K.M.; Aach, J.; Guell, M.; DiCarlo, J.E.; Norville, J.E.; Church, G.M. RNA-guided human genome engineering via Cas9. Science 2013, 339, 823-826. [CrossRef]

199. Ahmar, S.; Saeed, S.; Khan, M.; Khan, S.U.; Mora-Poblete, F.; Kamran, M.; Faheem, A.; Maqsood, A.; Rauf, M.; Saleem, S.; et al. A Revolution toward Gene-Editing Technology and Its Application to Crop Improvement. Int. J. Mol. Sci. 2020, 21, 5665. [CrossRef]

200. Song, G.; Jia, M.; Chen, K.; Kong, X.; Khattak, B.; Xie, C.; Li, A.; Mao, L. CRISPR/Cas9: A powerful tool for crop genome editing. Crop J. 2016, 4, 75-82. [CrossRef]

201. Shi, J.; Gao, H.; Wang, H.; Lafitte, H.R.; Archibald, R.L.; Yang, M.; Hakimi, S.M.; Mo, H.; Habben, J.E. ARGOS 8 variants generated by CRISPR Cas9 improve maize grain yield under field drought stress conditions. Plant Biotechnol. J. 2017, 15, 207-216. [CrossRef]

202. Pyott, D.E.; Sheehan, E.; Molnar, A. Engineering of CRISPR/Cas9 mediated potyvirus resistance in transgene free Arabidopsis plants. Mol. Plant Pathol. 2016, 17, 1276-1288. [CrossRef] [PubMed]

203. Chandrasekaran, J.; Brumin, M.; Wolf, D.; Leibman, D.; Klap, C.; Pearlsman, M.; Sherman, A.; Arazi, T.; Gal-On, A. Development of broad virus resistance in non-transgenic cucumber using CRISPR/Cas9 technology. Mol. Plant Pathol. 2016, 17, 1140-1153. [CrossRef]

204. Wang, L.; Chen, L.; Li, R.; Zhao, R.; Yang, M.; Sheng, J.; Shen, L. Reduced drought tolerance by CRISPR/Cas9-mediated SIMAPK3 mutagenesis in tomato plants. J. Agric. Food Chem. 2017, 65, 8674-8682. [CrossRef]

205. Shen, C.; Que, Z.; Xia, Y.; Tang, N.; Li, D.; He, R.; Cao, M. Knock out of the annexin gene OsAnn3 via CRISPR/Cas9-mediated genome editing decreased cold tolerance in rice. J. Plant Biol. 2017, 60, 539-547. [CrossRef]

206. Ueta, R.; Abe, C.; Watanabe, T.; Sugano, S.S.; Ishihara, R.; Ezura, H.; Osakabe, Y.; Osakabe, K. Rapid breeding of parthenocarpic tomato plants using CRISPR/Cas9. Sci. Rep. 2017, 7, 1-8. [CrossRef] [PubMed]

207. Li, R.; Zhang, L.; Wang, L.; Chen, L.; Zhao, R.; Sheng, J.; Shen, L. Biotechnology and biological transformations CRISPR/Cas9Mediated SICBF1 mutagenesis reduces tomato plant chilling tolerance. J. Agric. Food Chem. 2018, 66, 9042-9051. [CrossRef]

208. Tashkandi, M.; Ali, Z.; Aljedaani, F.; Shami, A.; Mahfouz, M.M. Engineering resistance against Tomato yellow leaf curl virus via the CRISPR/Cas9 system in tomato. Plant Signal. Behav. 2018, 13, e1525996. [CrossRef]

209. Liu, H.; Soyars, C.L.; Li, J.; Fei, Q.; He, G.; Peterson, B.A.; Meyers, B.C.; Nimchuk, Z.L.; Wang, X. CRISPR/Cas9-mediated resistance to cauliflower mosaic virus. Plant Direct 2018, 2, e00047. [CrossRef]

210. Macovei, A.; Sevilla, N.R.; Cantos, C.; Jonson, G.B.; Slamet-Loedin, I.; Čermák, T.; Voytas, D.F.; Choi, I.; Chadha-Mohanty, P. Novel alleles of rice eIF4G generated by CRISPR/Cas9 targeted mutagenesis confer resistance to Rice tungro spherical virus. Plant Biotechnol. J. 2018, 16, 1918-1927. [CrossRef]

211. Zhang, A.; Liu, Y.; Wang, F.; Li, T.; Chen, Z.; Kong, D.; Bi, J.; Zhang, F.; Luo, X.; Wang, J.; et al. Enhanced rice salinity tolerance via CRISPR / Cas9-targeted mutagenesis of the OsRR22 gene. Mol. Breed. 2019, 39, 1-10. [CrossRef]

212. Okada, A.; Arndell, T.; Borisjuk, N.; Sharma, N.; Watson-Haigh, N.; Tucker, E.J.; Baumann, U.; Langridge, P.; Whitford, R. CRISPR/Cas9-mediated knockout of Ms1 enables the rapid generation of male-sterile hexaploid wheat lines for use in hybrid seed production. Plant Biotechnol. J. 2019, 17, 1905-1913. [CrossRef] [PubMed]

213. Chen, S.; Zhang, N.; Zhang, Q.; Zhou, G.; Tian, H.; Hussain, S.; Ahmed, S.; Wang, T.; Wang, S. Genome editing to integrate seed size and abiotic stress tolerance traits in Arabidopsis reveals a role for DPA4 and SOD7 in the regulation of inflorescence architecture. Int. J. Mol. Sci. 2019, 20, 2695. [CrossRef] [PubMed]

214. Paixão, J.F.R.; Gillet, F.-X.; Ribeiro, T.P.; Bournaud, C.; Lourenço-Tessutti, I.T.; Noriega, D.D.; De Melo, B.P.; De Almeida-Engler, J.; Grossi-De-Sa, M.F. Improved drought stress tolerance in Arabidopsis by CRISPR/dCas9 fusion with a Histone AcetylTransferase. Sci. Rep. 2019, 9, 1-9. [CrossRef]

215. Kis, A.; Hamar, É.; Tholt, G.; Bán, R.; Havelda, Z. Creating highly efficient resistance against wheat dwarf virus in barley by employing CRISPR/Cas9 system. Plant Biotechnol. J. 2019, 17, 1004-1006. [CrossRef] [PubMed]

216. Zheng, M.; Zhang, L.; Tang, M.; Liu, J.; Liu, H.; Yang, H.; Fan, S.; Terzaghi, W.; Wang, H.; Hua, W. Knockout of two Bna MAX 1 homologs by CRISPR/Cas9 targeted mutagenesis improves plant architecture and increases yield in rapeseed (Brassica napus L.). Plant Biotechnol. J. 2020, 18, 644-654. [CrossRef]

217. Zeng, Y.; Wen, J.; Zhao, W.; Wang, Q.; Huang, W. Rational improvement of rice yield and cold tolerance by editing the three genes OsPIN5b, GS3, and OsMYB30 with the CRISPR-Cas9 system. Front. Plant Sci. 2020, 10, 1663. [CrossRef] [PubMed]

218. Usman, B.; Nawaz, G.; Zhao, N.; Liu, Y.; Li, R. Generation of High Yielding and Fragrant Rice (Oryza sativa L.) Lines by CRISPR/Cas9 targeted mutagenesis of three homoeologs of cytochrome P450 gene family and OsBADH2 and transcriptome and proteome profiling of revealed changes triggered by mutations. Plants 2020, 9, 788. [CrossRef] [PubMed]

219. Kumar, V.V.S.; Verma, R.K.; Yadav, S.K.; Yadav, P.; Watts, A.; Rao, M.V.; Chinnusamy, V. CRISPR-Cas9 mediated genome editing of drought and salt tolerance (OsDST) gene in indica mega rice cultivar MTU1010. Physiol. Mol. Biol. Plants 2020, 26, 1099-1110. [CrossRef] 
220. Faal, P.G.; Farsi, M.; Seifi, A.; Kakhki, A.M. Virus-induced CRISPR-Cas9 system improved resistance against tomato yellow leaf curl virus. Mol. Biol. Rep. 2020, 47, 3369-3376. [CrossRef]

221. Soyk, S.; Müller, N.A.; Park, S.J.; Schmalenbach, I.; Jiang, K.; Hayama, R.; Zhang, L.; Van Eck, J.; Jiménez-Gómez, J.M.; Lippman, Z.B. Variation in the flowering gene SELF PRUNING 5G promotes day-neutrality and early yield in tomato. Nat. Genet. 2017, 49, 162-168. [CrossRef]

222. Li, C.; Liu, C.; Qi, X.; Wu, Y.; Fei, X.; Mao, L.; Cheng, B.; Li, X.; Xie, C. RNA guided Cas9 as an in vivo desired target mutator in maize. Plant Biotechnol. J. 2017, 15, 1566-1576. [CrossRef] [PubMed]

223. Zhou, H.; He, M.; Li, J.; Chen, L.; Huang, Z.; Zheng, S.; Zhu, L.; Ni, E.; Jiang, D.; Zhao, B. Development of commercial thermosensitive genic male sterile rice accelerates hybrid rice breeding using the CRISPR/Cas9-mediated TMS5 editing system. Sci. Rep. 2016, 6, 1-12. [CrossRef]

224. Li, M.; Li, X.; Zhou, Z.; Wu, P.; Fang, M.; Pan, X.; Lin, Q.; Luo, W.; Wu, G.; Li, H. Reassessment of the four yield-related genes Gn1a, DEP1, GS3, and IPA1 in rice using a CRISPR/Cas9 system. Front. Plant Sci. 2016, 7, 377. [CrossRef] [PubMed]

225. Jia, Y.; Ding, Y.; Shi, Y.; Zhang, X.; Gong, Z.; Yang, S. The cbfs triple mutants reveal the essential functions of CBF s in cold acclimation and allow the definition of CBF regulons in Arabidopsis. New Phytol. 2016, 212, 345-353. [CrossRef]

226. Lou, D.; Wang, H.; Liang, G.; Yu, D. OsSAPK2 confers abscisic acid sensitivity and tolerance to drought stress in rice. Front. Plant Sci. 2017, 8, 993. [CrossRef]

227. Ali, Z.; Abulfaraj, A.; Idris, A.; Ali, S.; Tashkandi, M.; Mahfouz, M.M. CRISPR/Cas9-mediated viral interference in plants. Genome Biol. 2015, 16, 1-11. [CrossRef]

228. Ji, X.; Zhang, H.; Zhang, Y.; Wang, Y.; Gao, C. Establishing a CRISPR-Cas-like immune system conferring DNA virus resistance in plants. Nat. Plants 2015, 1, 1-4. [CrossRef]

229. Zhan, X.; Zhang, F.; Zhong, Z.; Chen, R.; Wang, Y.; Chang, L.; Bock, R.; Nie, B.; Zhang, J. Generation of virus resistant potato plants by RNA genome targeting. Plant Biotechnol. J. 2019, 17, 1814-1822. [CrossRef]

230. Zhang, Y.; Bai, Y.; Wu, G.; Zou, S.; Chen, Y.; Gao, C.; Tang, D. Simultaneous modification of three homoeologs of Ta EDR 1 by genome editing enhances powdery mildew resistance in wheat. Plant J. 2017, 91, 714-724. [CrossRef]

231. Nadakuduti, S.S.; Enciso-Rodríguez, F. Advances in genome editing with CRISPR systems and transformation technologies for plant DNA manipulation. Front. Plant Sci. 2021, 11, 2267. [CrossRef]

232. Montecillo, J.A.V.; Chu, L.L.; Bae, H. CRISPR-Cas9 system for plant genome editing: Current approaches and emerging developments. Agronomy 2020, 10, 1033. [CrossRef]

233. Ren, Q.; Zhong, Z.; Wang, Y.; You, Q.; Li, Q.; Yuan, M.; He, Y.; Qi, C.; Tang, X.; Zheng, X.; et al. Bidirectional promoter-based CRISPR-Cas9 systems for plant genome editing. Front. Plant Sci. 2019, 10, 1173. [CrossRef]

234. Andersson, R.; Sandelin, A. Determinants of enhancer and promoter activities of regulatory elements. Nat. Rev. Genet. 2020, 21, 71-87. [CrossRef] [PubMed]

235. Kantor, A.; McClements, M.E.; MacLaren, R.E. CRISPR-Cas9 DNA base-editing and prime-editing. Int. J. Mol. Sci. 2020, 21, 6240. [CrossRef] [PubMed]

236. Anzalone, A.V.; Koblan, L.; Liu, D.R. Genome editing with CRISPR-Cas nucleases, base editors, transposases and prime editors. Nat. Biotechnol. 2020, 38, 824-844. [CrossRef]

237. Anzalone, A.V.; Randolph, P.B.; Davis, J.R.; Sousa, A.A.; Koblan, L.W.; Levy, J.M.; Chen, P.J.; Wilson, C.; Newby, G.A.; Raguram, A.; et al. Search-and-replace genome editing without double-strand breaks or donor DNA. Nature 2019, 576, 149-157. [CrossRef] [PubMed] 